Предраг Ј. Мутавџић*

https://doi.org/10.18485/analiff.2018.30.2.9

Дина Дмитровић

$811.163 .41 ' 373.7$

$811.14 ' 373.7$

Универзитет у Београду

811.135.1'373.7

Филолошки факултет

Anastassios L. Kampouris

Originalni naučni rad

Democritus University of Thrace

Primljen: 07.09.2018.

Faculty of Humanities and Social Studies

Prihvaćen: 12.11.2018.

\title{
ФРАЗЕОЛОГИЗМИ СА КЉУЧНОМ РЕЧЈУ НОВАЦ У САВРЕМЕНОМ ГРЧКОМ, РУМУНСКОМ И СРПСКОМ ЈЕЗИКУ **
}

\author{
Беше некаgа време каgа се буgала лако растајала оg новща. \\ Саgа се йо gешава свакоїа gана свакоме. \\ (Adlai E. Stevensen III, 1900-1950; амерички дипломата \\ и политичар)
}

Основну окосницу овога рада представљају фразеологизми који су изведени (формирани) било уз помоћ примарне лексеме новаи / йара (йаре) у три савремена балканска језика, грчком, румунском и српском језику, било неке секундарне лексеме (попут їрош, йалир, крајцара и слично) која се такође односи на новац, а која је у ранијим историјским периодима била у оптицају. Све забележене фразеологизме разматрамо понајпре компаративно, потом и контрастивно. На крају рада смо се укратко осврнули и на статистичке податке до којих смо дошли током анализе. Основни закључак који се намеће јесте да између наведених језика превагу односи фразеолошки нулти степен структурне еквиваленције, док семантички ниво еквиваленције углавном припада делимично подударној категорији. У неку руку, ово није за чуђење, будући да је човеков однос према новцу, са једне стране, мање-више универзалан, али му је, са једне стране, у сваком језику приписана посеб-

* Поштанска адреса: Филолошки факултет, Катедра за неохеленске студије, Студентски трг 3, 11000 Београд. Контакт (e-mail): predrag.mutavdzic@fil.bg.ac.rs

** Рад је написан у оквиру пројекта Министарства науке, просвете и техничког напретка Републике Србије Језищии и кулимуре у времену и иростиору (број 178002). 
Предраг J. Мутавџић, Дина Дмитровић, Anastassios L. Kampouris

на улога и значај због посебних друштвено-културолошких условљености. Отуда су разматрани балкански језици пре хомотипични него идиотипични. Овај рад би уједно могао бити од користи у виду предлога (смерница) за најадекватније или најприближније преношење фразеологизама приликом превођења са неког или на неки од разматраних балканских језика.

Кључне речи: новац, савремени грчки, румунски, српски, фразеологизми, еквиваленција.

\section{1. Уводно разматрање}

У својој књизи На ваш новач се рачуна ${ }^{1}$ амерички финансијски стручњак Хауард Дејтон навео је како се у Библији новац и сви појмови везани за имућно стање, или поседовање материјалних вредности, наводе тачно 2.350 пута. То је далеко више од свих појмова који се односе на Христове речи о љубави и поштовању или, чак, о рају и паклу заједно. Да је новац тај који знатно ремети односе међу људима у друштву, било да је реч о блиским члановима унутар породице, било шире сагледано, о појединцима који сачињавају једну заједницу, Библија недвосмислено указује у истој оној мери у којој се подвлачи и то да његово поседовање и среброљупство најчешће заслепљују човека, постајући ако не главни, а онда свакако један од најважнијих критеријума процене, вредновања и одабира људи. Отуда је главна порука Библије да је највећа вредност, највеће богатство које човек може икада поседовати, управо оно које се тиче не материјалног (дакле, спољашњег), него духовног (унутрашњег). Међутим, људска је природа ипак пре склона да себи удовољава него да се одриче, а уколико је удовољавање могуће остварити путем новца, тада се све моралне и обзирне ограде најчешће и потиру. Одвајкада новац има неодољиву, безмало хипнотичку моћ дубоко везану за појединца у већој или мањој мери, а што се да̂ сагледати у непосредном односу сваког појединца према новцу.

Није сасвим тачно, како се данас уврежено схвата, да је новац у нашем добу постао доминантан чинилац људског живота. Изгледа да је овакво схватање зачето од онога тренутка када је човек почео да га кује и да му (при)даје одређену вредност. Додатно, новац, баш

1 Howard Dayton. (1997). Your money counts. The Biblical Guide to Earning, Spending, Saving, Investing, Giving and Getting Out of Debt. Tyndalle House Publishers. 
ФРАЗЕОЛОГИЗМИ СА КЉУЧНОМ РЕЧЈУ НОВАЦ У САВРЕМЕНОМ ...

као и сваки други материјални предмет, поседује тек симболичко значење које се, од друштва до друштва, од културе до културе, знатно мења, и поред тога што му је суштина иста - да буде готов посредник. Управо симболика новца се може илустровати следећим примером: у највећем броју друштава постоји новчаница на којој је одштампана бројевна ознака 500 - и док у некој друштвеној заједници то може бити нечија цела месечна плата, у некој другој је то тек довољно за млеко и хлеб на дневном нивоу. Из тог разлога новац представља веома посебну „društvenu vezu sa dva lica, licem nužnosti i obveza, te licem otvaranja prema razmjeni i povjerenju“ (Aglietta-Orléan, 2004: 37). Из тог разлога је могуће рећи како је новац наша и (насушна) потреба, али и завист у форми посебне „животне енергије“ која пружа у истој мери и моћ и задовољство, без обзира на њихову врсту.

На Балканском полуострву, а посебно код Јужних Словена, и данас се задржало древно веровање да ће, уколико се у кући држи метла са дршком окренутом надоле, домаћинство увек имати новца. По својој прилици древно је и веровање како никада нећемо бити без новца, под условом да у новчанику држимо кованице тако да су увек главом окренуте према власнику новчаника. Још једно од веома распрострањених народних балканских веровања каже да се никоме не позајмљује хлеб и/ или со, с обзиром да се тиме призива оскудица и немаштина у новчаном погледу, отприлике у оном распону коју носи пословична изрека у виду клетве gабоїgа имао, йа немао, чије се ауторство приписује Јеврејима.

Наша друштвено-породично стечена, а потом кроз живот индивидуално развијена, навика да будемо у одређеној мери емотивно везани за новац се у савременом потрошачком друштву испољава преко добро смишљених и циљаних рекламних кампања у којима се појединац подстиче да троши новац. Отуда је више него јасно зашто је некада тешко бити homo economicus, пре свега рационалан: превагу односи наше лично задовољство и позитивно емоционално стање у односу на потребу да се здраворазумски приступи куповини и, самим тим, трошењу новца. Једна релативно скорашња медицинска студија (Camerer et al, 2005; посебно видети стране 31-42) недвосмислено је показала како постоји директна веза између оштећења мозга, тачније фронталног кортекса, и импулсивног трошења новца: најчешћи узрок оваквом понашању последица је неког обољења које доводи до смањења способности појединца да економски одлучује, односно 
да се рационално односи према новцу. Како се види из радова друге групе научника (Spinella et al, 2007; Spinella et al, 2008), главни циљ њиховог проучавања тицао се покушаја да се установи на који су начин повезани понашање и однос према новцу код пунолетних испитаника с установљеним психичким потешкоћама које су настале као директна последица физичког (органског) оштећења мозга. У анализу су укључили и особине личности као и њихове навике у вези са трошењем новца. Главни закључак до кога су дошли јесте следећи - сви испитаници, код којих је уочена већа дисфункција префронталног кортекса, новац су схватали као средство којим:

a) искључиво задивљују своју непосредну околину,

б) знатно могу утицати на друге људе, посебно на њихово понашање и на дружење,

в) се постиже успех у друштву, и то искључиво у облику моћи и каквог престижа.

Као општа карактеристика свих испитаника испољила се та да су много мање бринули о обезбеђивању финансијске сигурности у својој будућности, што недвосмислено показује да је новац за њих везан само за садашњи тренутак и за садашње (тренутне) потребе. С обзиром да је одусуство свести о било каквом планирању штедње (или уштеде) непозната когнитивна категорија (прецизније речено, категорија само као идеја постоји, али се уопште не узима у ментално разматрање), према њој се испитаници нису рационално поставили.

Сва ова сазнања се сасвим лепо уклапају у запажања Вебера и сарадника (Weber et al, 2009) како је средњи префронтални кортекс одговоран за пружање најразличитијих представа о новцу, будући да се у њему формирају сва наша појмовна испољавања (одређења, схватања, вредност, односи итд.) према њему. У том погледу надметање између рационалног и емотивног расуђивања, рационалног и (не)ограниченог трошења новца код сваког појединца представља праву борбу између реалног и иреалног, корисног (односно, потребног) и беспотребног (дакле, оног не нужног). Како се чини, ниједно друштво позитивно не сагледава расипничко трошење новца (обично је везано за раскалашност и разметање), већ за штедњу, стварање и увећавање богатства, али исто тако се негативно односи и према (претераном) шкртарењу и тврдичлуку баш као и према стицању богатства на непоштен или грамзив начин. 
ФРАЗЕОЛОГИЗМИ СА КљУЧНОМ РЕЧЈУ НОВАЦ У САВРЕМЕНОМ ...

\section{2. Циљ и методологија рада, корпус}

Главни циљ рада оличен је у контрастивном и компаративном сагледавању фразеолошких јединица одабраних на основу кључне речи новач у три несродна савремена балканска језика - у српском, као полазном, те у грчком и румунском као циљним. Међутим, уколико имамо у виду да компаративан приступ нужно захтева сагледавања и из обратног правца, полазни језик може бити и било који други од наведених, будући да се у сваком од њих фразеолошка слика формира углавном на посебне начине, следећи оне принципе творбе фразеологизама који су за тај језик од значаја.

За потребе овога рада, као и због потребе да будемо методолошки доследни, определили смо се да све идиоматске конструкције називамо двојако - фразеологизмима или фразеолошким јединицама (конструкцијама) - не залазећи при томе у сва пропратна теоријска тумачења и сагледавања у вези са њиховим именовањима, класификацијама и одређењима која се могу пронаћи у релевантној лингвистичкој литератури. У оквир фразеологизама уврстили смо и све забележене паремије које се, због своје стабилне структуре, посматрају у релевантној литератури као посебна (под)врста фразеолошких конструкција, с обзиром да

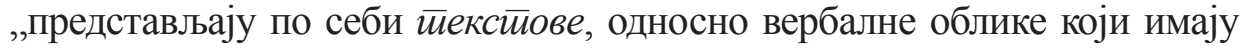
независно значење и који се могу употребљавати самостално“ (Пермяков, 1988: 83), што их, према њиховим унутрашњим одликама, умногоме приближава фразеолошким јединицама као чврстим (устаљеним) фразама (Мршевић-Радовић, 1987: 23), док се са лингвокултуролошке стране „културна информација чува у унутрашњој форми ових јединица и даје им национално-културни колорит“ (Маслова, 2007: 82).

Исто тако, у раду настојимо да, без обзира на смер кретања:

a) сагледамо колико постоји поклапање између посматраних фразеолошких структура,

б) пронађемо најбољи могући преводни еквивалент (односно, семантички парњак), те

в) да утврдимо да ли је могуће говорити о међујезичкој, међулексичкој и међусемантичкој подударности.

Сви примери код којих се појављује нулти степен структурно-семантичке еквиваленције означени су астериском, а подвучени су они 
код којих постоји делимична структурна еквиваленција (у виду различитих лексичких елемената). Ради што јаснијег увида у фразеолошку ситуацију, сви су примери на грчком и румунском језику дати као глосе, односно у заградама се налазе њихови буквални преводи. Такође, ради што јасније илустрације и аргументованости, применили смо у раду и статистичку методу чији је задатак да покаже степен еквиваленције у оквиру фразеолошке слике у наведеним балканским језицима.

Као извори ексцерпције грађе за анализу фразеологизама са кључном лексемом новач у наведеним језицима послужили су материјали традиционалног (затвореног) и модуларног (отвореног) типа. То ће рећи да смо се ослањали не само на све доступне речнике - и опште и фразеолошке - једнојезичне и двојезичне наведених балканских језика, укључујући ту и оне који се могу пронаћи на интернету као целокупна издања као online верзија (њихов потпуни списак приложен је на крају рада), него и на Google претраживач у својству помоћне (секундарне) форме провере како употребе тако и значења фразеологизама из корпуса².

\section{3. $\quad$ О новцу и његовој дефиницији}

Sooner or later, we sell out for money. Tony Randall (1920-2004)

На питање „шта је новац?“, могу се добити веома различити одговори, све у зависности од тога шта се под појмом новац подразумева. Као и све што се производи у друштву, и новац се посматра као опште богатство, односно као крајње специфична роба, која може задржати дуже времена своју вредност - зато је новац замена за злато, односно изједначен је са њиме ${ }^{3}-$ и куповну моћ. Отуда новац у сваком

2 Интернет претраживач је сасвим погодан у овом погледу, будући да има више могућности од једноставног претраживања интернета. Са друге стране, Google (или било који други доступан интернет претраживач) има своја одређена техничка и друга ограничења која се виде у томе да још није у стању да понуди довољан број језичких примера нити (све могуће) контексте употребе забележених фразеологизама из корпуса.

3 И данас злато у финансијским трансакцијама функционише као замена за новац, односно као покриће за њега. Познато је кроз историју да су једино злато и сребро били метали који су сами по себи представљали вредност. 
ФРАЗЕОЛОГИЗМИ СА КЉУЧНОМ РЕЧЈУ НОВАЦ У САВРЕМЕНОМ ...

друштву има (условно и/или дословно схваћено) привилеговану (безмало монополску) улогу такозваног универзалног еквивалента преко кога се неминовно преламају (изражавају, израчунавају, испољавају, квантификују...) углавном све вредности, самим тим и сва добра која се у једном друштву произведу или остваре [створе] на било који начин (Mishkin, 2007: 8). Другим речима, новац је посебна обрачунска јединица карактеристична за свако друштво. Италијански професор економије Грацијани изнео је две главне одреднице новца; по њему:

a) „новац је посредно средство размене, пошто се у оквиру савремених економија плаћање обавља искључиво новцем,

б) новац је облик богатства, пошто безмало свако може део или целокупно своје имање да држи у облику текућег салда“" (Graziani, 2003: 5).

Према већини признатих економиста, новац је посебна апстрактна категорија која се одређује као укупна прометна вредност богатства једног друштва, имајући у виду да се унутар њега путем новца обављају све (замисливе, остварљиве...) трансакције. Из тог разлога је новац универзално средство чија је сврха међусобно упоређивање и размена свих производа људског рада (Smithin, 2000: 14). Додатно, „новац је друштвена институција и јавно добро“ (Tobin, 20084), с обзиром да ,значајно смањује трошкове свих трансакција на које се односи“ (Păun, 2010: 7). Како Манкив наводи (Mankiw, 2006: 628), економско одређење новца подразумева једино оне облике богатства које продавци регуларно прихватају као замену за робу и услуге, попут готовине или такозваних хартија од вредности ${ }^{5}$.

Уколико се отвори било који општи речник и погледа како је дефинисана лексема новац, наилази се на следећа доступна тумачења:

А) у српском:

a) нарочито израђен метал или папир утврђене вредности, који издаје држава, а служи као средство плаћања,

4 http://www.dictionaryofeconomics.com/search_results? $q=$ silver $\% 20$ standard\&field $=$ keyword

5 Поседовање, на пример, акција означава нечије формално богатство, с обзиром да оне нису новац у правом смислу те речи, већ замена за њега. Зато нико не може у продавници куповати робу њима. 
b) метални комад, новчић, пара,

c) одређени (новчани) износ, сума,

d) богатство, капитал (РМС 3, 1967: 804)

Б) у грчком:

a) економско добро заједнички прихваћено као средство којим се купују и продају друга добра и услуге, а које функционише као мера њихове вредности,

b) званична валута, новчићи и папирне новчанице које издаје једна држава,

c) новчано имање, богатство којим појединац располаже,

d) ботатство и богати,

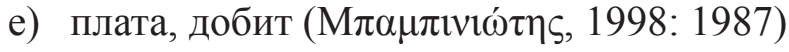

В) у румунском:

a) општи еквивалент вредности робе; метална или папирна монета препозната као средство плаћања и размене у једном друштву, одређена на основу друштвеног узуса са природном основом у злату,

b) у свакодневном говору папирна или кована новчаница ${ }^{6}$.

На основу изнетог упоредног прегледа увиђа се да се новац у начелу исто лексикографски одређује, те отуда овакав вид дефинисања у форми знања из речника (dictionary knowledge), које је, пре свега, практичног (приручног) и релативно поједностављеног карактера - како је Ланг назначио ,речник не представља теоријску конструкцију, већ је [чист] попис речи (Lang, 1983). Насупрот њега стоји такозвано енциклопедијско знање (encyclopedic knowledge) које унеколико друкчије дефинише појам новца. Тако, на пример, у Малој Просвеиииној енциилойеgији (књ. 3, 1978: 674-675) стоји код одреднице новац следеће објашњење:

\section{новаи}

1. среgсивво које йосреgује у размени роба: комая мейала, ис-

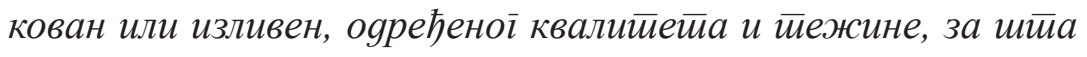
жиіом јамчи юеїов издавалаи, служи као среgсиво у ироме-

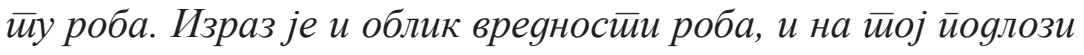

6 http://dexonline.net/definitie-ban 
ФРАЗЕОЛОГИЗМИ СА КЉУЧНОМ РЕЧЈУ НОВАЦ У САВРЕМЕНОМ ...

има разне функиије у оквиру робне размене; израз је и чинилаи иривреgне и кулитурне иситорије.

2. новаи као ойшйа роба је роба која у оквиру робноі светиа има йосебну функиију, йј. [...] айсолуйна је роба чија је gрушитвена улоїа gа буgе израз вреgносиии свих gруіих роба,

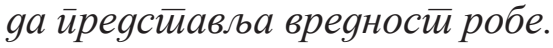

док се у Хрвайској енциклойеgији Лексикографског завода „Мирослав Крлежа“ наводи како је

novac - institucionalno sredstvo koje vjerovnik na osnovi društvene konvencije ili zakonske obveze prihvaća uzeti od dužnika za pokriće njegovih obveza koje mogu nastati na osnovi različitih transakcija (sv. 7, 2005: 756).

Из указаних цитата се увиђа да се ове дефиниције у знатној мери подударају са дефиницијама новца претходно изнетих у оквиру ускостручног (економског) одређења, али опет поседују и неке своје одлике које их од тог одређења удаљавају.

\section{4. О лексемама за именовање новца}

У савременом грчком, румунском и српском језику, поред основне лексеме којом се означава одређена (или неодређена) количина новчане вредности, постоји барем још једна лексема која је у равноправној употреби у свакодневном говору и која улази у фразеолошке конструкције. У грчком фигурирају три лексеме - две изворне (до-

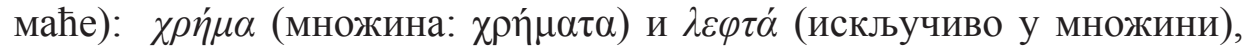

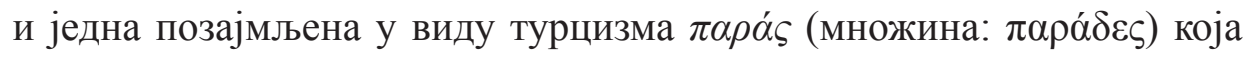
је раширена и у свим осталим балканским језицима. У румунском, уз овај турцизам (para), у напоредној употреби је и лексема $b_{a n i}{ }^{7}$.

7 Етимологија ове лексеме је и данас неразјашњена. Према неким још недовољно потврђеним виђењима, има везе са мађарском и словенском титулом бан / bán $(<$ протокелтски *bāno-), с обзиром да су у средњем веку угарским и румунским областима управљали банови који су имали право да 
Истоветну ситуацију запажамо и у српском - поред лексеме новац, фигурира и лексема $\bar{u} а р a$ / $\bar{u} а р е$. Назначимо и то да је алтернативна употреба ових лексема свакако просторно условљена, будући да се у наведеним језицима директно осликавају сви некадашњи културни додири и утицаји који су допирали из оријенталне сфере. У том погледу може се рећи да су ово базичне (или примарне) лексеме у апсолутном парасинонимијском односу уз које стоји и низ других лексема, понајпре оних жаргонских, колоквијалних, каква је, на пример, лексема лова, која као таква још постоји у румунском (не и у грчком), или кинйа (само у српском).

Поред ових лексема, оно што смо приметили на основу сакупљене грађе јесте и то да су у сва три језика задржани бројни пређашњи називи за новац који је некада био у оптицају дуже или краће време у различитом историјском тренутку. У питању су такозване секундарне лексеме које се и даље употребљавају у свакодневном говору, можда више у жаргону, регионално или у оквиру породице, а свакако су различитог етимолошког порекла, као што су

А) у румунском ${ }^{8}$ :

a) латинског: arginți (у слободном преводу „новчићи“") $)^{9}=$ бели новии $=\tau \alpha \dot{\alpha} \sigma \pi \rho \alpha$

b) мађарског: pițulă (< picula /=,„новчић“/)

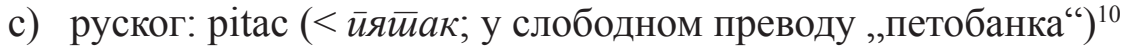

d) турског: mangăr $\left(<\right.$ mangir $\left.{ }^{11}\right)$, para $^{12}$

кују свој новац. Са друге стране, Ћоранеску (Ciorănescu, 2002: 76) сматра да је у питању средњевековни латински термин banus (у значењу „порез“, „разрез“) који је првобитно заживео у разговорном немачком као Ban да би потом ушао у румунски преко мађарског.

8 Професор романистике Коман Лупу објавио је књигу под насловом Из истиорије именовања монейа у румунском језику (Din istoricul numelor de monede în limba română, București: Editura Universității din București, 2006) y којој је пружио детаљне и веома занимљиве податке у вези са свим монетама које су биле у оптицају у румунским земљама у периоду од 15. до 19. столећа.

9 Реч је о лексеми латинског порекла чији је основно значење „сребрњаци“.

10 Назив у руском изворно означава новчић од пет копејки.

11 У турском језику је некада означавала ситан бакарни новчић, док у данашњем турском аргоу има еквивалент лексеми лова.

12 У турском се и данас под овом речју подразумева ковани новац, односно новчић без обзира на његову вредност. 
ФРАЗЕОЛОГИЗМИ СА КЉУЧНОМ РЕЧЈУ НОВАЦ У САВРЕМЕНОМ ...

e) украјинског: sorocovăț $(<\text { сороковец })^{13}$, lăscaie / lățcaie $(<$ ляцки $)^{14}$

f) ромског: lovele (< lovo; cf: лова $)^{15}$;

g) француског: franc

h) немачког: sfanț (< Zwanzig/er/) creițar(i) $(<$ Kreuzer) groș ( $<$ Grosch $<$ grossus /латински/; cf: грош) ort $(<$ Ort)

Занимљиво би овде било напоменути да се унутар овог списка речи налазе и две чије је етимолошко порекло и даље непознато, или недовољно разјашњено, а то су:

i)mardei

j)gologan ${ }^{16}$

а чији би преводни еквиваленти највише одговарале српској лексеми йаре. Све наведене румунске лексеме (под а-е, као и i-j) данас означавају новац мале вредности, дакле „сића“, „ситнина“, „ситниш“.

Б) у српском:

a) лова

b) кинта ${ }^{17}$ (< албански: qintar $=$ „новчић“)

c) пенези ${ }^{18}$, филер (< мађарски: pénz /= „новац“/, fillér $r^{19}$ )

13 Некада је ова лексема означавала сребрни новчић чија се вредност, у зависности од територије на којој је била у оптицају, мењала (Украјина, Русија, Молдавија, Влашка).

14 Реч је о бакарном новчићу који се у румунским земљама употребљавао све до средине 18. столећа, а чија је вредност била око пола паре.

15 И у мађарском се чује ова реч, додуше више у разговорном језику и у сленгу -lové.

16 И поред тога што извесна тумачења говоре у прилог словенском корену, глава (руски іолова), она су недовољно утемељена.

17 И у бугарском постоји истоветна лексема - кинии $и$ (= пари).

18 Више као регионална реч у Војводини, Славонији и Барањи.

19 Филер је стоти део форинте. Све до 1992. године био је у оптицају када га је званично повукла Мађарска народна банка (Magyar Nemzeti Bank). 
d) марјаш (< мађарски: márias $\left.^{20}\right)$

е) крајцара (< немачки: Kreuzer)

f) цвоњак (< немачки: Zwanzig/er/)

g) грош

В) у грчком, које су двојаке :

- са једне стране су страног, понајпре западноевропског, порекла, као што су наредне:

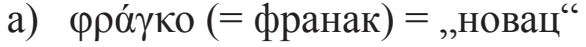

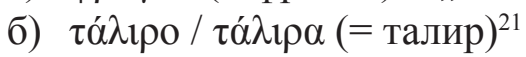
в) $\varphi \lambda$ oupí / $\varphi \lambda \omega \rho i ́(=$ флорин $)=$ „новац“'22
г) $\mu \pi 1 \kappa 1$ кívi $\alpha(<$ piccolo $)=$ „ситнина“, „сића“"
д) $\pi \varepsilon \kappa o v ́ v 1 \alpha(<$ латински ресипіа) $=$,лова““
Ђ) $\mu \pi \alpha \gamma$ ióко $(<\text { baiocco })^{23}=$,паретине“, „гомила пара / велике паре““
e) $\gamma \rho o ́ \sigma \mathrm{l}(=,, г р о ш “)$

- са друге стране су то изворне грчке лексеме, али са новим придодатим (метафоричким) значењем, као што су:

ж) $\mu \alpha \lambda \lambda i ́(=$, „лака“, „влас“, „коса“, „вуна“) = „лова“

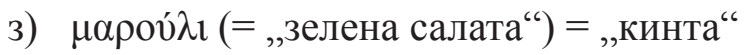

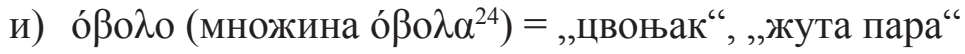

20 Назив потиче од апелатива Марија (Mária). У питању је сребрњак кован за време владавине угарске краљице Марије Анжујске (1371-1395) на коме је писало с обе стране moneta Marie.

21 Пре увођења евра, ова лексема је означавала новчаницу од пет драхми, сада од пет евра. Најчешће се употребљава у множини и тада носи значење „велике / добре паре“, ,пуно пара“.

22 Напоменимо овде једну културолошку занимљивост: да се и даље у чесницу код Грка ставља само „флорин“.

23 Значење овог италијанизма је у грчком померено: изворно, у италијанском се од средњега века па до 1865. године њиме указивало на новац веома мале вредности (пару).

24 Наведена лексема је препознатљива у српском у оквиру усвојене речи обол. У старој Атини шест сребрних обола чинило је једну драхму. Да обол ипак није био „ситнина“, наводи у својој књизи Дејвидсон, указујући да је, на пример, цена времена проведеног са куртизаном обично износила три обола (Davidson, 1998: 59). 
ФРАЗЕОЛОГИЗМИ СА КЉУЧНОМ РЕЧЈУ НОВАЦ У САВРЕМЕНОМ ...

- j) $\chi \alpha \rho \tau o u ́ \rho \alpha^{25}=$, ,ићa“

а које се углавном односе, како и преводни еквиваленти показују, на малу своту новца, дакле на „сићу“, „парице“, „ситнину“ и слично.

Како се може сагледати из датог прегледа, највећи број и даље задржаних лексема за означавање новца у сва три језика је страног порекла.

\section{5. Фразеологизми са речју новац}

Укупан број свих забележених фразеолошких конструкција, укључујући и пословице, са неком од лексема за именовање новца у назначеним језицима јесте 239 , а по језицима то изгледа овако:

\begin{tabular}{lll} 
грчки: & 65 & $26,53 \%$ \\
румунски: & 96 & $39,18 \%$ \\
српски: & 84 & $34,28 \%$ \\
& & \\
\hline укупно: & 245 & $100,00 \%$
\end{tabular}

\section{1. О комутацији лексема унутар фразеологизама. Подударност фразеологизама.}

Оно што се даิ приметити јесте да се у сва три језика запажа комутација примарних лексема унутар појединих фразеолошких контрукција, што јасно показује колико су оне и формално, и функционално, и семантички апсолутно изједначене; на пример:

25 Ова лексема означава бакшиш који су обично музичари добијали у кафани. 
Предраг J. Мутавџић, Дина Дмитровић, Anastassios L. Kampouris

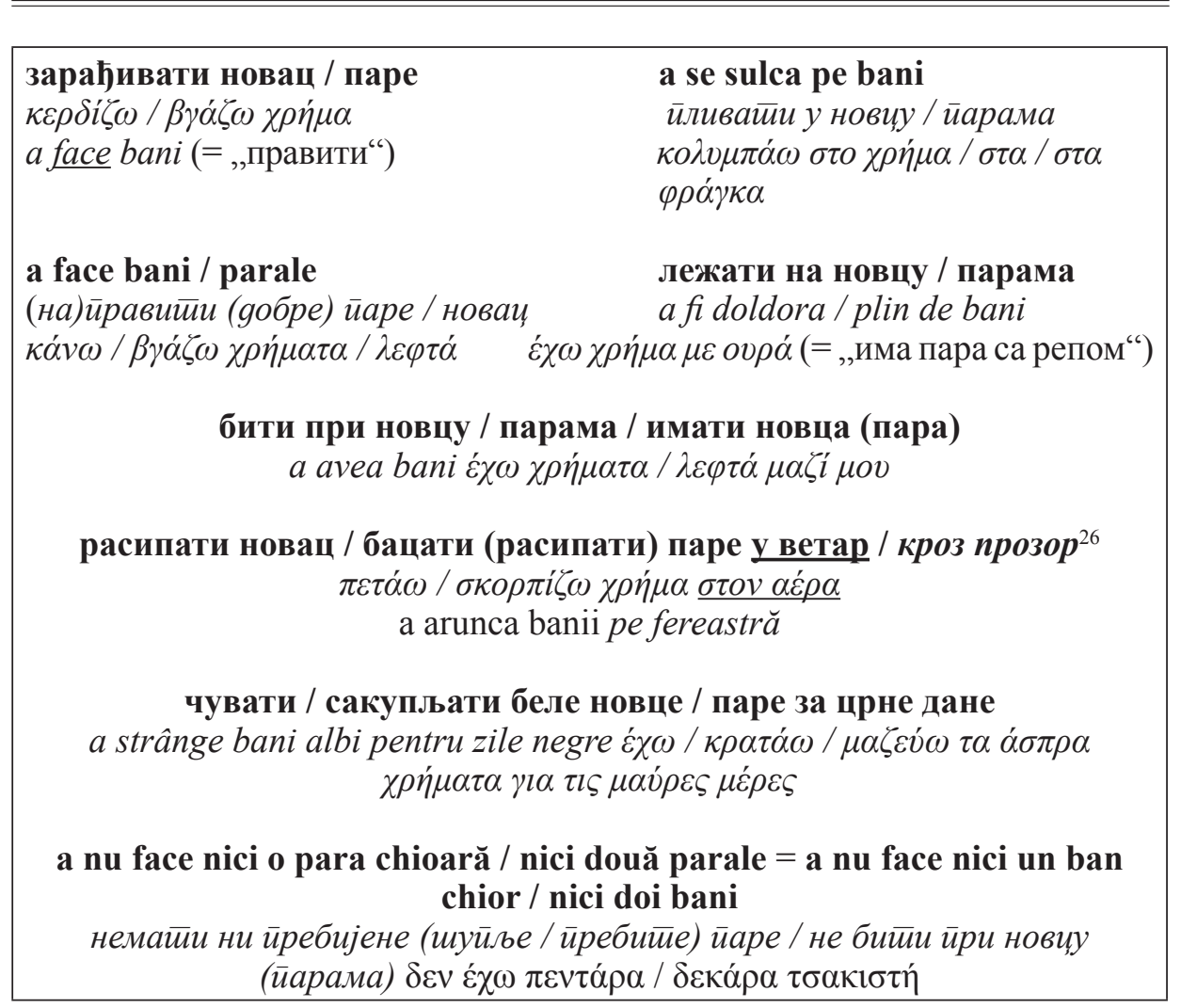

Како се може приметити из изнетих примера, комутација се не појављује у сва три језика, негде је она сасвим подударна, понегде је само делимична:

\section{за мале / ситне новце / паре

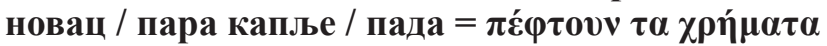

Када је реч о новцу, незаобилазна је и тематика мита која се у разматраним балканским језицима исказује на безмало исти начин. И овде је могућа комутација расположивих лексема, све у зависно-

26 Упоредиво с истим фразеолошким конструкцијама у италијанском: gettare il denaro dalla finestra, франиуском: jetar l argent par la fenêtre и немачком: Geld beim Fenster rauswerfen, док се у енглеском запажа делимично промењена унутрашња (морфосинтаксичка) структура: to throw money down the drain. У албанском, као и у грчком, постоји само варијанта у којој се новац баца у ветар: $i$ hedh paratë nё erë. 
ФРАЗЕОЛОГИЗМИ СА КЉУЧНОМ РЕЧЈУ НОВАЦ У САВРЕМЕНОМ ...

сти од језика. Док у српском фигурира само једна лексема - митио - која се препознаје и у румунском као mită (будући преузета из словенског вокабулара), у румунском се још употребљава и грцизам filodormă. У грчком турцизам $\mu \pi \alpha \xi i \sigma l$ поседује значење које је, у односу на српски, донекле проширено те, осим напојнице (= „бакшиш“, три језика се врло често запажа и у говору и у писаним медијима не само аналитички глагол којим се означава подмићивање:

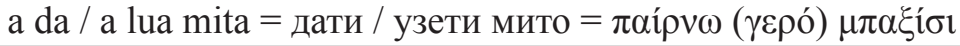

него и синтетички:

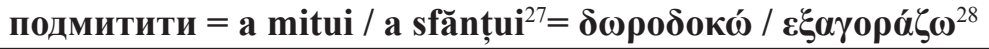

Са друге стране, у савременом румунском се за ознаку напојнице равноправно употребљавају две лексеме страног порекла - једна словенског - răsplată, а друга турског - bacșiș, те обе учествују у грађењу само по једног фразеологизма: док први бинарни după faptă și răsplata (= „према делу и награда“) нема својих адекватних парњака у српском и грчком, а приближно би се могао пренети као:

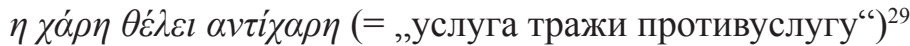
gобро се добрим враћа

дотле је други a oferi un bacșiș унеколико амбивалентан, означавајући, у непосредној зависности од контекста, или йонуgийи

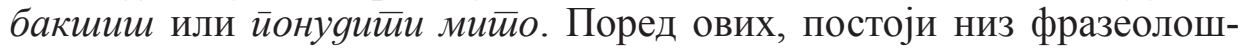
ких конструција где комутација лексема није могућа, што зависи од сваког језика понаособ. Ово јасно говори у прилог томе да су оне и даље индивидуализоване те посебно значењски, стилски и лексички обојене, као што се то види у наредним фразеологизмима:

27 У основи овог глагола налази се германизам.

28 Смисао овог глагола би одговарао српском „поткупити“.

29 Први пут је овај израз забележен код Еурипида у 1234. стиху његове траге-

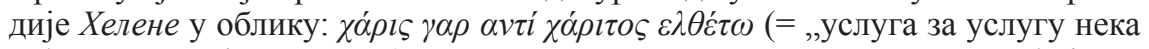
дође“; McHugh, 2009: 67). У изразу на савременом грчком примећује се поједностављена синтакса, при чему је фокус са финалне позиције глагола пребачен на изведену сложеницу ( $\alpha \nu \tau i ́ \chi \alpha \rho \eta)$. У овом поступку је тако предлог замењен префиксом, а императив глагола његовим индикативом презента, што, свеукупно сагледано, није довело до битније промене значења израза. 
бити без пребијене паре

a nu avea (nici) un ban

$\delta \varepsilon v{ }^{\varepsilon} \chi \omega$ ov́ $\tau \varepsilon \lambda \varepsilon \pi \tau o^{30}$ fără nici un ban

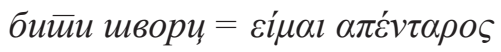

/ $\alpha \delta \dot{\varepsilon} \kappa \alpha \rho о \varsigma / \alpha ́ \alpha \rho \alpha \gamma \kappa o \varsigma$

згртати / направити паре

a face bani / parale

$\kappa \dot{\alpha} v \omega / \beta \gamma \dot{\alpha} \zeta \omega \lambda \varepsilon \varphi \tau \dot{\alpha} / \chi \rho \dot{\eta} \mu \alpha \tau \alpha$

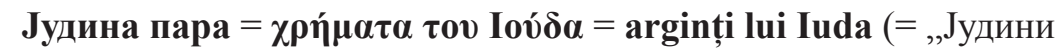
сребрњаци")

знати (кога) као пару на длану

a ști câte parale face (cineva) (= ,знати колико пара чине /некога/“)

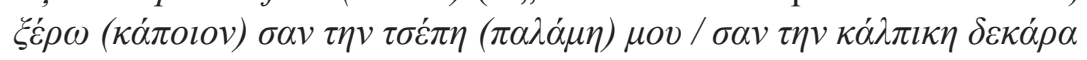

(= ,знати /кога/ као свој џеп /длан/; као подмуклу десетицу“)

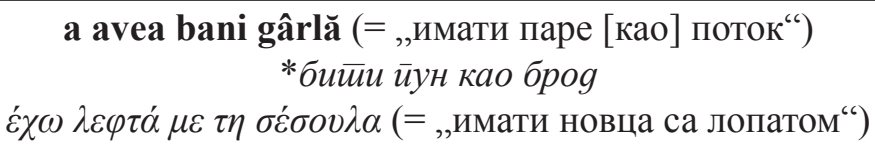

a avea bani strânși la ciorap (= „имати сакупљене паре у чарапи“)

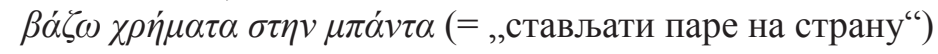
чуватии йаре на іомили

a lua (ceva) de / drept bani buni (= „узети /шта/ право [као] добре паре“)

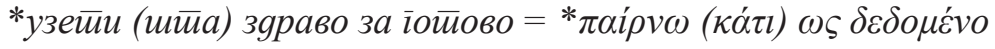

извући и последњу пару од (кога)

a stoarce de bani pe (cineva)

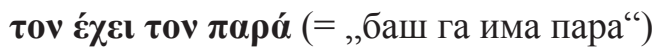

битии човек оg новй / хоће їа йара

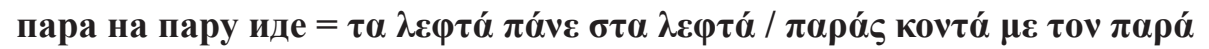

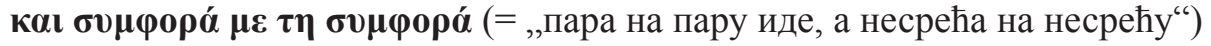
bani fac pe bani = ban(ul) la ban trage = ban pe ban

momește (= „пара чини пару / пара привлачи пару / пара мами пару“)

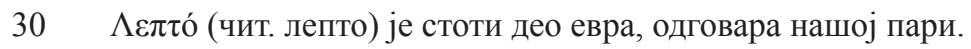


ФРАЗЕОЛОГИЗМИ СА КЉУЧНОМ РЕЧЈУ НОВАЦ У САВРЕМЕНОМ ...

У извесном броју данас релативно устаљених колокација такође одсуствује могућност лексичке комутације у сва три језика. Понајпре, реч је о калковима насталим према узорима (моделима) из језика економије с енглеског говорног подручја, попут:

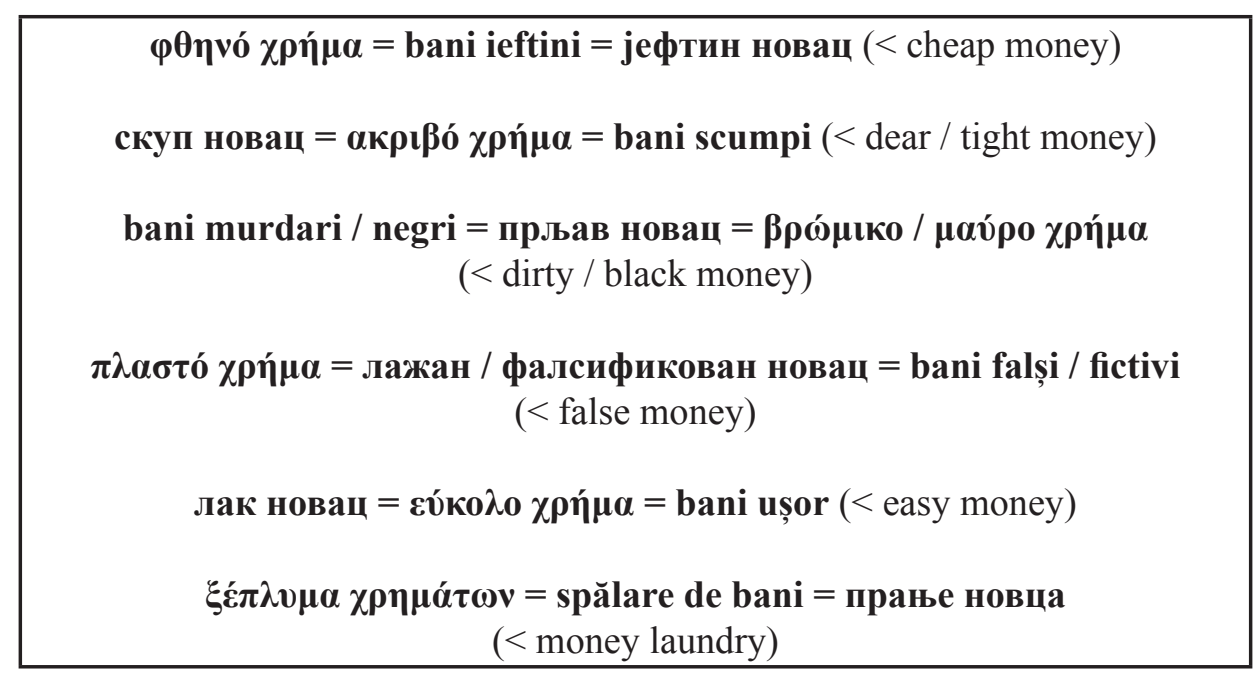

У ову категорију сврстава се и изрека time is money која је у

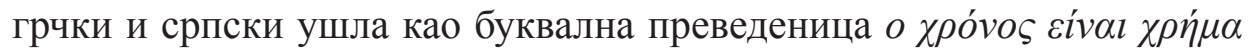
/ време је новач, док је у румунском унеколико модификована: timpul inseamnă bani (= „време значи /означава/ новац“').

Занимљиво би било назначити како се у свим забележеним фразеологизмима у којима се као кључна компонента јавља нека од ранијих нумизматичких лексема по правилу не јавља комутација, односно да су то сада већ прилично чврсте структуре. У румунском једино лексеме sfant, groș, lăscaie, ort те franc формирају следеће фразеологизме: 
Предраг J. Мутавџић, Дина Дмитровић, Anastassios L. Kampouris

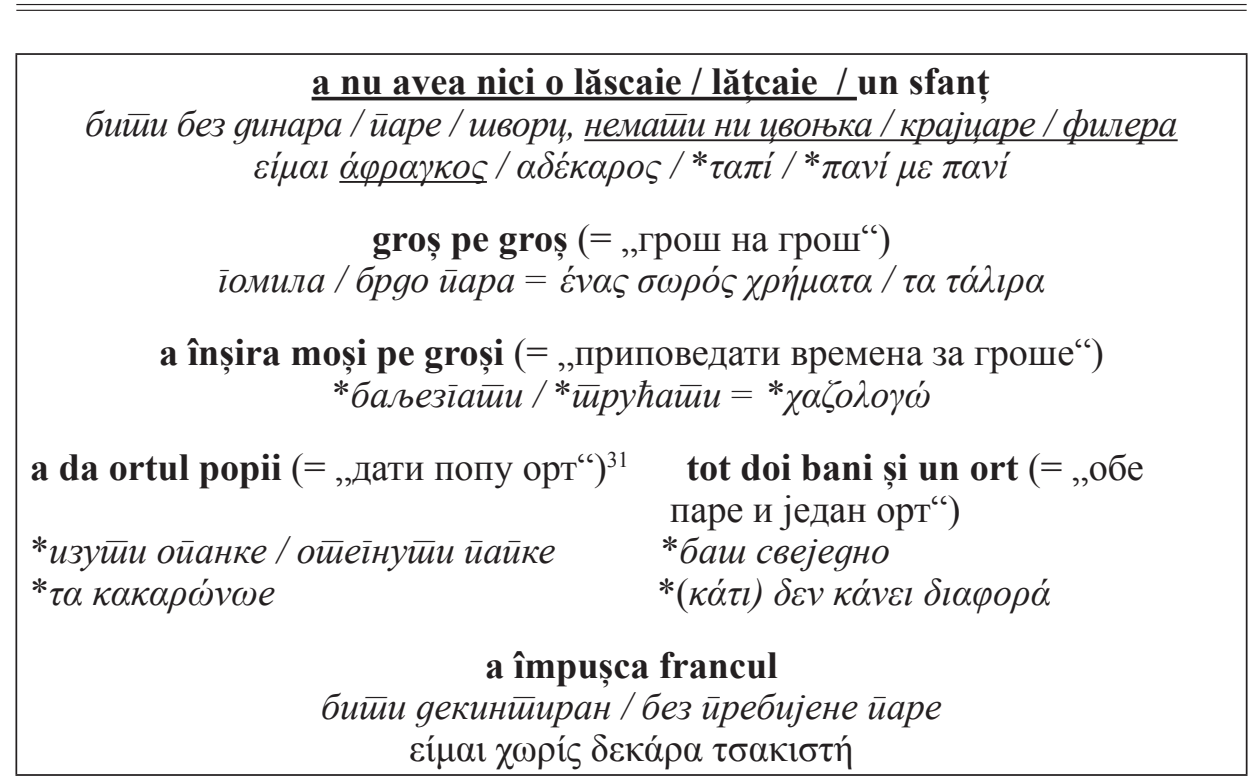

У српском се већи број фразеолошких конструкција формира уз помоћ секундарне нумизматичке лексеме ірош:

\begin{tabular}{|c|}
\hline 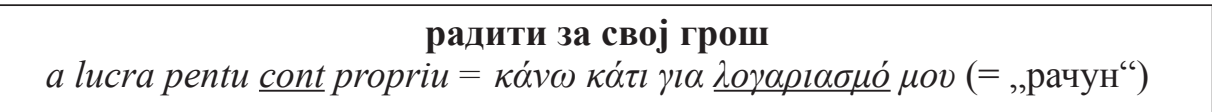 \\
\hline 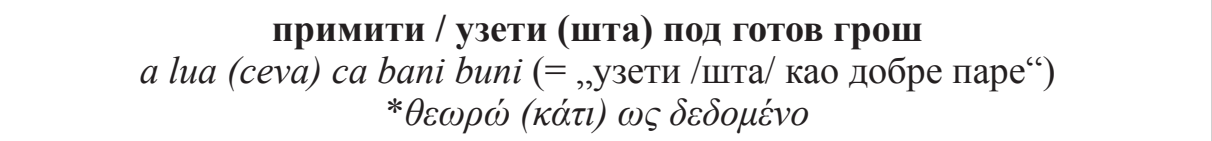 \\
\hline $\begin{array}{c}\text { радити за пребијен грош } \\
\pi \alpha i \rho v \omega / \kappa \varepsilon \rho \delta i \zeta \omega \delta \varepsilon \kappa \alpha ́ \rho \alpha \tau \sigma \alpha \kappa l \sigma \tau \dot{\eta}\end{array}$ \\
\hline 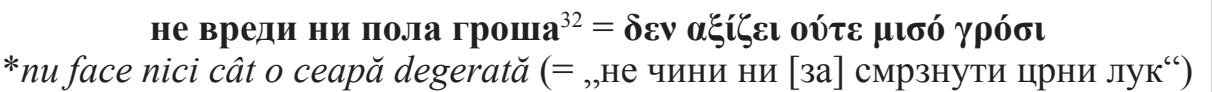 \\
\hline
\end{tabular}

31 Орт је у био сребрни средњовековни новчић, вредности четвртине немачког талира. Код Румуна је постојао обичај да се свештеник плати управо ортом као накнадом за његов излазак на гробље. Отуда се данас ова фразеолошка конструкција употребљава са значењем да је неко умро.

32 Упоредиво са: не вреgи ни йола луле gувана. У језичком изразу Румуна из Војводине чује се у свакодневном говору конструкција која је калкирана управо према наведеном српском фразеологизму - nu face cât o lulea de tutun - и која се не препознаје у румунском у Румунији и Молдавији. 
ФРАЗЕОЛОГИЗМИ СА КЉУЧНОМ РЕЧЈУ НОВАЦ У САВРЕМЕНОМ ...

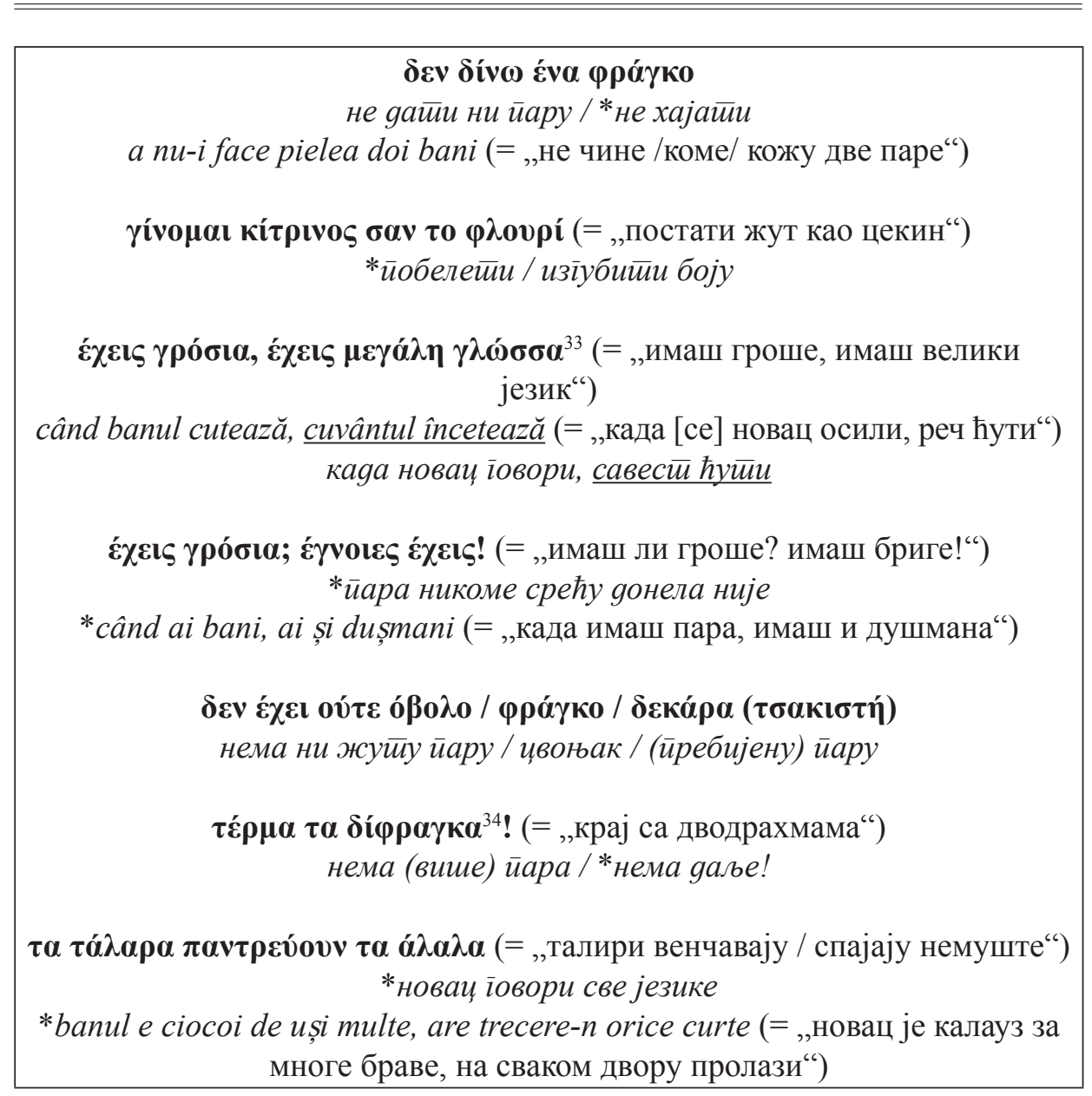

\section{2. Делимична подударност фразеологизама}

Другу категорију фразеологизама представљају они код којих се уочава делимична подударност која се, у зависности од језика, испољава преко одређених структурних померања. Њихов семантички смисао је углавном непромењен, односно могуће га је (условно речено, релативно лако) препознати у неком од циљних језика / у циљним језицима:

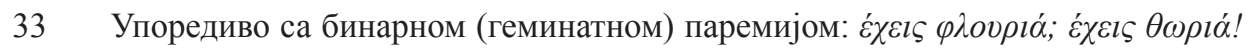
(= „имаш ли цекине? имаш изглед“).

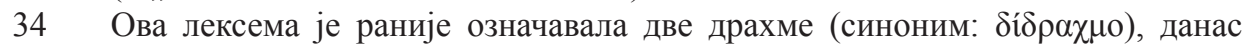
кованицу од два евра. 
Предраг J. Мутавџић, Дина Дмитровић, Anastassios L. Kampouris

лежати на парама / купати се у парама = a se scălda în bani

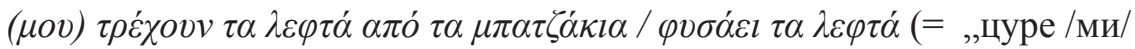
паре из ногавица“/, „дува у паре“)

не вреди ни две паре / ни пет пара / ни жуту банку

a nu face (nici) o para chioară / nici două parale / a nu da doi bani

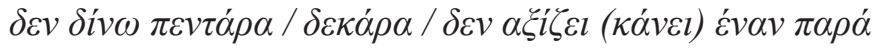

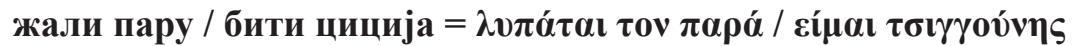
a lega paraua cu zece noduri (= „везати пару са десет чворова“") / a fi zgârcit

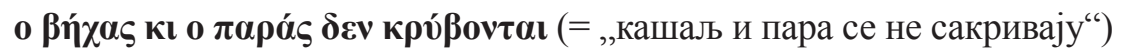

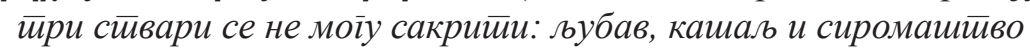
boala și sărăcia nu se pot ascunde (= „бол и сиромаштво се не могу сакрити“)

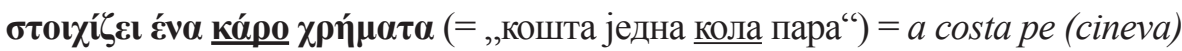
o groază de bani (= „,коштати /кога/ грозоту пара“")

*коийа Ђаво и $\bar{u} o^{35}$

не можеш имати и јаре и паре / и овце и новце

* nu poți fi şi cu varza unsă şi cu slănina în pod / şi satul și cu punga plină nu se poate (=,„не можеш бити и са масним купусом и са сланином на тавану“ / „и сит, и пуне $\underline{\text { кесе }}^{36}$ се не може“")

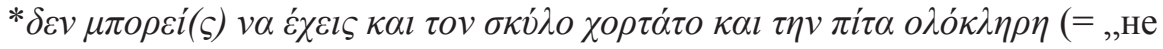
може/ш/ да имаш и пса ситога и целу питу“)

У последњем наведеном примеру уочава се потпуна структурна неподударност између српског, румунског и грчког фразеологизма, али је зато њихова семантичка вредност апсолутно изједначена.

У сва три разматрана језика запазили смо по један фразеологизам истог семантичког домена - уз незнатне структурне (пре свега, лексичке) разлике - којим се јасно имплицира да свако од нас има право на уживање (опуштање, одмарање...):

35 Упоредиво још са румунским: *este scump al dracului (= „скуп/о/ је ђаволски“),

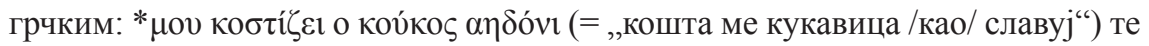

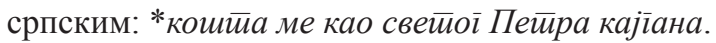

36 Овде се под кесом подразумева мала кожна врећа која је обично висила око врата и служила за ношење новца. 
ФРАЗЕОЛОГИЗМИ СА КЉУЧНОМ РЕЧЈУ НОВАЦ У САВРЕМЕНОМ ...

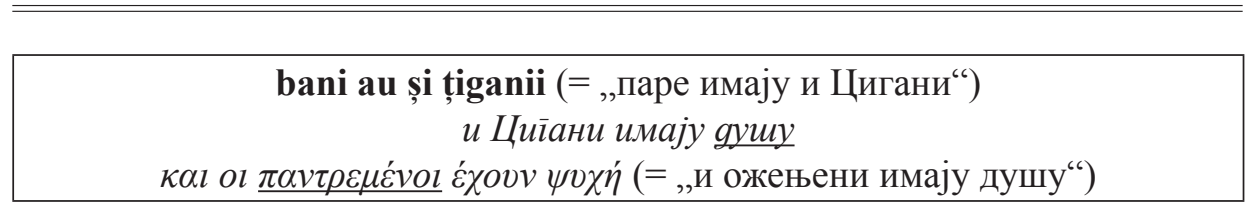

Колико је присутан јак међујезички утицај између српског и румунског, можда најбоље може илустровати следећи румунски фразеологизам у форми калка који код Румуна у Банату гласи потпуно исто као и у српском:

имати пара / новца као плеве / блата $=$ a avea bani ca pleava

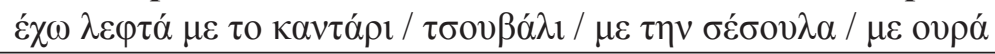

а који се, као такав, не препознаје у званичном румунском: $a \mathrm{fi}$ doldora / plin de bani. Нека нам буде допуштено да назначимо и следеће - како је словенски утицај у овом погледу био знатан и у мађарском, отуда се у мађарском формирао потпуно идентичан фразеологизам са српским: annyi a pénze, mint a pelyva.

\section{3. Нулта категорија подударности фразеологизама}

На основу извршеног контрастивно-компаративног упоређења види се и да један број преводних еквивалената полазних фразеолошких конструкција припада категорији нулте структурно-семантичке подударности, а такви су и наредни: 
Предраг J. Мутавџић, Дина Дмитровић, Anastassios L. Kampouris

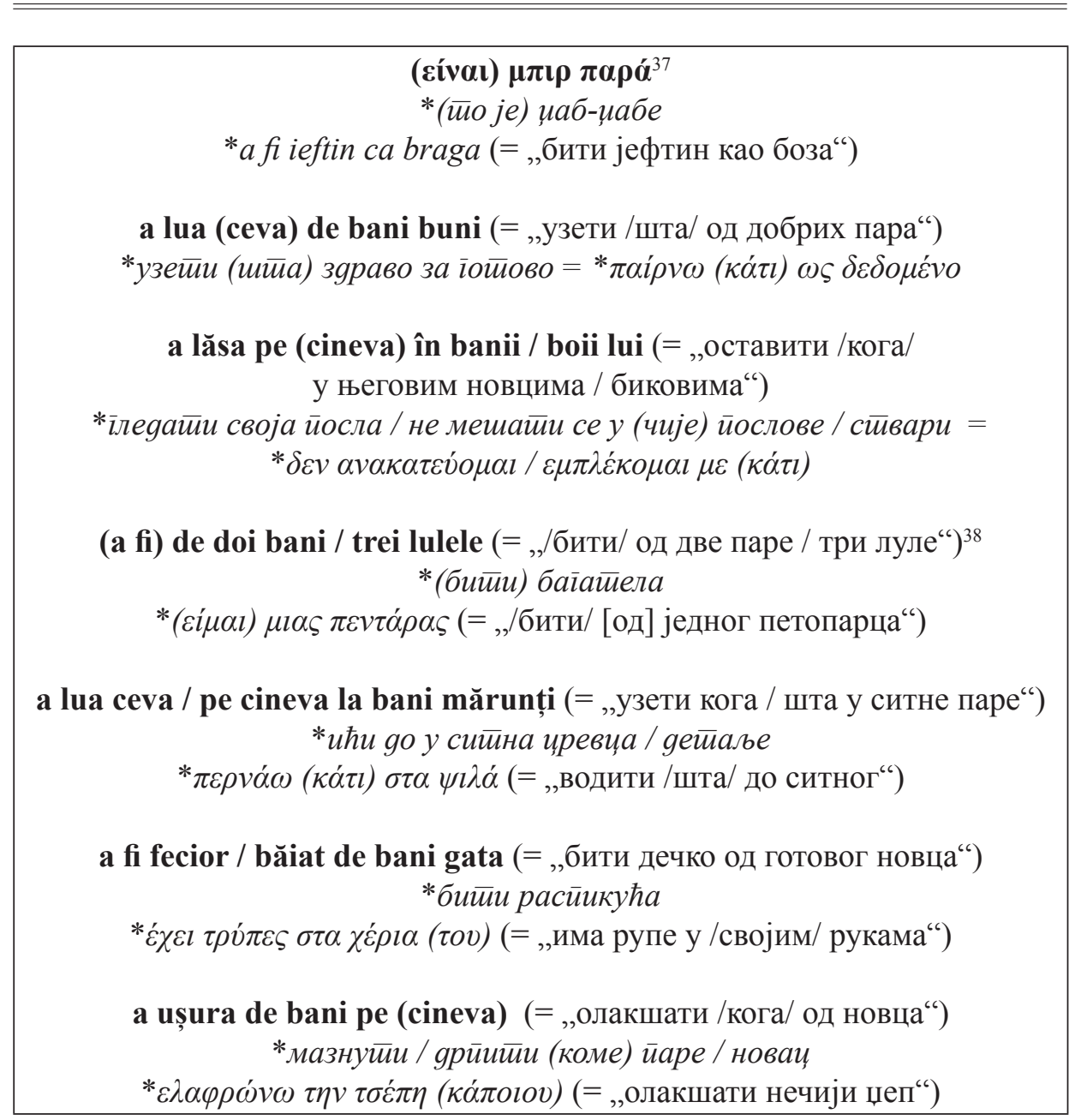

\section{6. О семантици фразеологизама са компонентом новац у грчком, румунском и српском језику}

У социолошком, а понајпре у психолошком, погледу поседовање новца одувек је код човека изазивало различита понашања и неретко га је (до) водило у разна искушења. То понајбоље изражавају две румунске паремије:

37 Реч је о преузетом фразеологизму из турског језика: bir para (буквално: „/за/ једну пару“).

38 Овде је смисао да се укаже да је реч о роби рђавог квалитета, тј. бофл роби. 
ФРАЗЕОЛОГИЗМИ СА КЉУЧНОМ РЕЧЈУ НОВАЦ У САВРЕМЕНОМ ...

a) banul e ochiul dracului (=, „пара је око ђавола“) која би се могла пренети на српски путем две пословичне изреке: новаu je gyшоіубаи, односно новаи је ловац. Обе, баш као и румунска, подвлаче негативан смисао, указујући на погубност и опасност коју новац носи са собом;

б) banul face din om neom (= „новац човека чини нечовеком“). Смисао ове паремије је такође негативан, будући да указује на то да новац може врло лако преокренути човекову природу, односно да поседовање (велике количине) новца мења човекову ћуд.

Са друге стране, у грчком језику постоји паремија у којој се запажа и негативна и позитивна страна поседовања новца које дочаравају управо глаголи изведени од лексема „пакао“ (ко́ $\lambda \alpha \sigma \eta)$ и „светац“

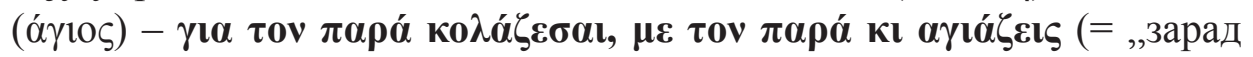
новца одлазиш у пакао, новцем и светац постајеш“). Основна јој је порука да човек због новца и пада у велико искушење, али је истовремено у стању да њиме чини и бројна добра дела.

Исто тако, немање (довољно) новца, односно непоседовање материјалног богатства, се у српском и у румунском изража преко наредне истоветне фразеолошке конструкције путем поређења:

има пара као жаба длака = e plin de bani ca broasca de păr

Њоме се на врло ироничан и саркастичан начин означава неко да је сасвим без пара (колоквијално речено, гоља). Нестварно поређење између првог (позитивног) и другог (негативног) дела служи да би се подвукло „претходно искуство засновано на стварном контексту (...) [при чему] је значење другог дела ироничних фразема контраст или негација тврдње исказане у првом делу. И зато се та два дела не могу раздвајати“ (Шипка, 2011: 29). У грчком овакав или сличан фразеологизам није забележен. Са друге стране, оно што издваја грчки у односу на румунски и српски су фразеолошке конструкције образоване уз помоћ лексеме $\mu \alpha \lambda \lambda i$ (= „длака“, „влас“, „вуна“) која, како смо претходно навели, припада групи секундарних лексема за означавање новца. Таквих је свега неколико: 
Предраг J. Мутавџић, Дина Дмитровић, Anastassios L. Kampouris

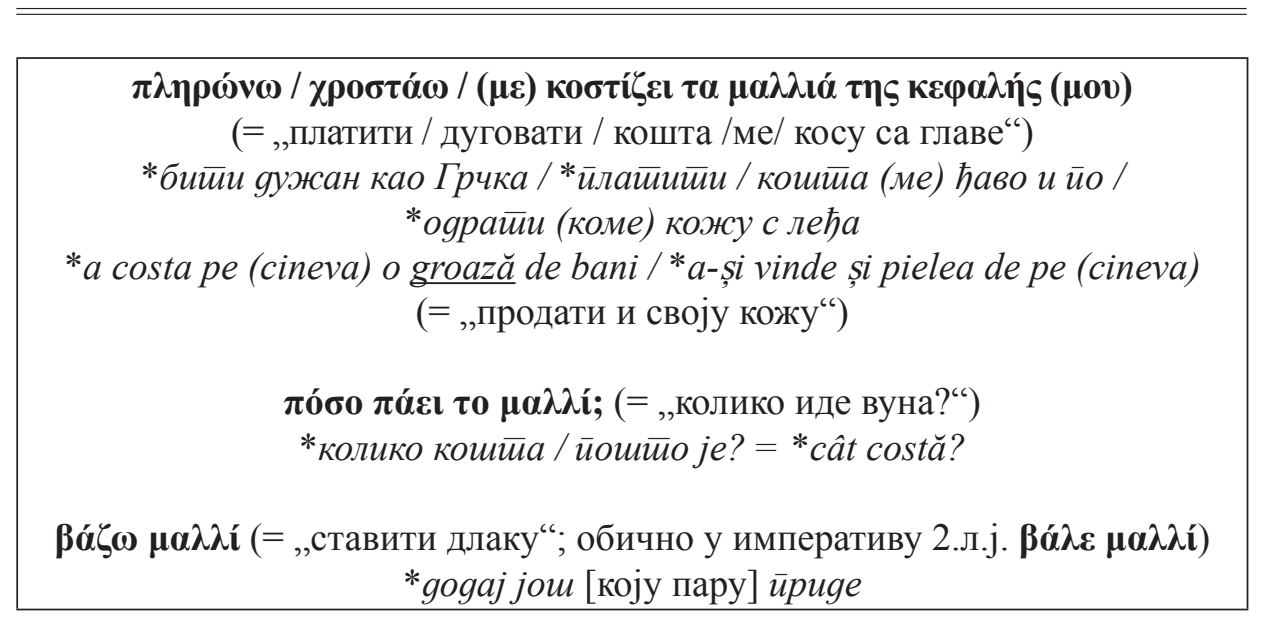

Да је новац тај који, у социјалном погледу, ствара посебне односе одавно је познато. Како су те везе, по правилу, релативно краткотрајне, будући да почивају искљичиво на материјалној (или каквој другој сличној обостраној) користи, њих понајбоље илуструју наредне паремије забележене у српском и румунском које су прилично подударне између себе у структурном погледу, а у семантичком апсолутно:

док је пара, има и другара; неста пара, неста и другара!

ai bani, ai prieteni; $n$-ai bani, $n$-ai prieteni! (= „имаш пара, имаш пријатеља; немаш пара, немаш ни пријатеља“)

dacă vrei să scapi de un prieten, imprumută-i bani (= ,,ако хоћеш да се ослободиш пријатеља, позајми му паре“) = ако желиш изгубити пријатеља, посуди му новац

Њихов би одговарајући пандан била наредна паремија у грчком:

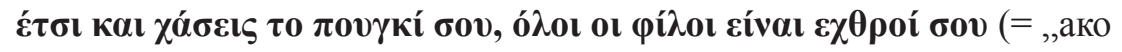
изгубиш новчаник, сви пријатељи су ти непријатељи“)

Са друге стране, у сва три језика запажају се паремије које говоре супротно - да су измирени рачуни управо ти који стварају праве

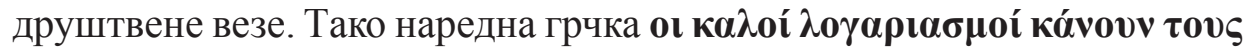

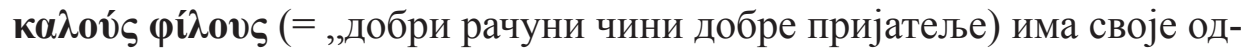
говарајуће парњаке у српском и румунском (који су између себе сасвим структурно-семантички подударни): 
ФРАЗЕОЛОГИЗМИ СА КЉУЧНОМ РЕЧЈУ НОВАЦ У САВРЕМЕНОМ ...

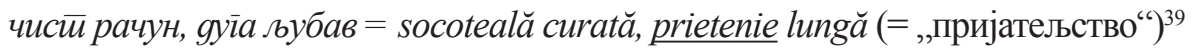

Безмало истог семантичког садржаја се наведеној грчкој приближавају следеће паремије на румунском и српском (без структурне подударне, док се семантички могу само донекле изједначинити):

frate, frate, dar brânza-i pe bani (= „брат, брат, али сир му за паре [дај]“) ако смо браћа, сестире нам нису кесе

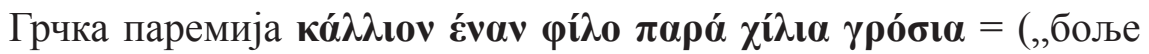
[је имати] једног пријатеља, него хиљаду гроша“)

a) и структурно и семантички је подударна са румунском un prieten face mai mult decât o pungă cu bani (=,,један пријатељ чини више него кеса с новцима“");

б) само је семантички приближна српској йријайељ је најбоља имовина у живойу.

Насупрот ових мудрих поука, налази се сасвим друкчије схватање које вели да није срамота бити богат, већ (пуки) сиромах. Одавно је познато да је људска природа грамзива и похлепна те да је склона новцу и гомилању материјалног богатства. И поред тога што је добро познато да новац „никоме не доноси срећу“, у оквиру друштвених односа се уврежило схватање, највероватније од најранијих дана робно-новчане производње, да се новцем (односно, богатством које из њега проистиче) стиче у друштву углед, благонаклоност, (страхо)поштовање, уважавање, (висок) положај те моћ. У том погледу новац функционише у друштву као својеврсни „чаробни штапић“ којим се може углавном све решити и постићи. Из тог су разлога веома интересантне наредне паремије које су за сваки разматрани језик посебне, што ће рећи да, иако између њих у потпуности одсуствују структурне подударности, семантички проносе поруку (смисао) - новцем је могуће све купити, добити, остварити, новац је заједнички језик који свима привлачи пажњу:

39 У румунском постоји још једна слична паремија која гласи: socoteală deasă e frăție aleasă (= „густ рачун је истакнуто братство“), 
Предраг J. Мутавџић, Дина Дмитровић, Anastassios L. Kampouris

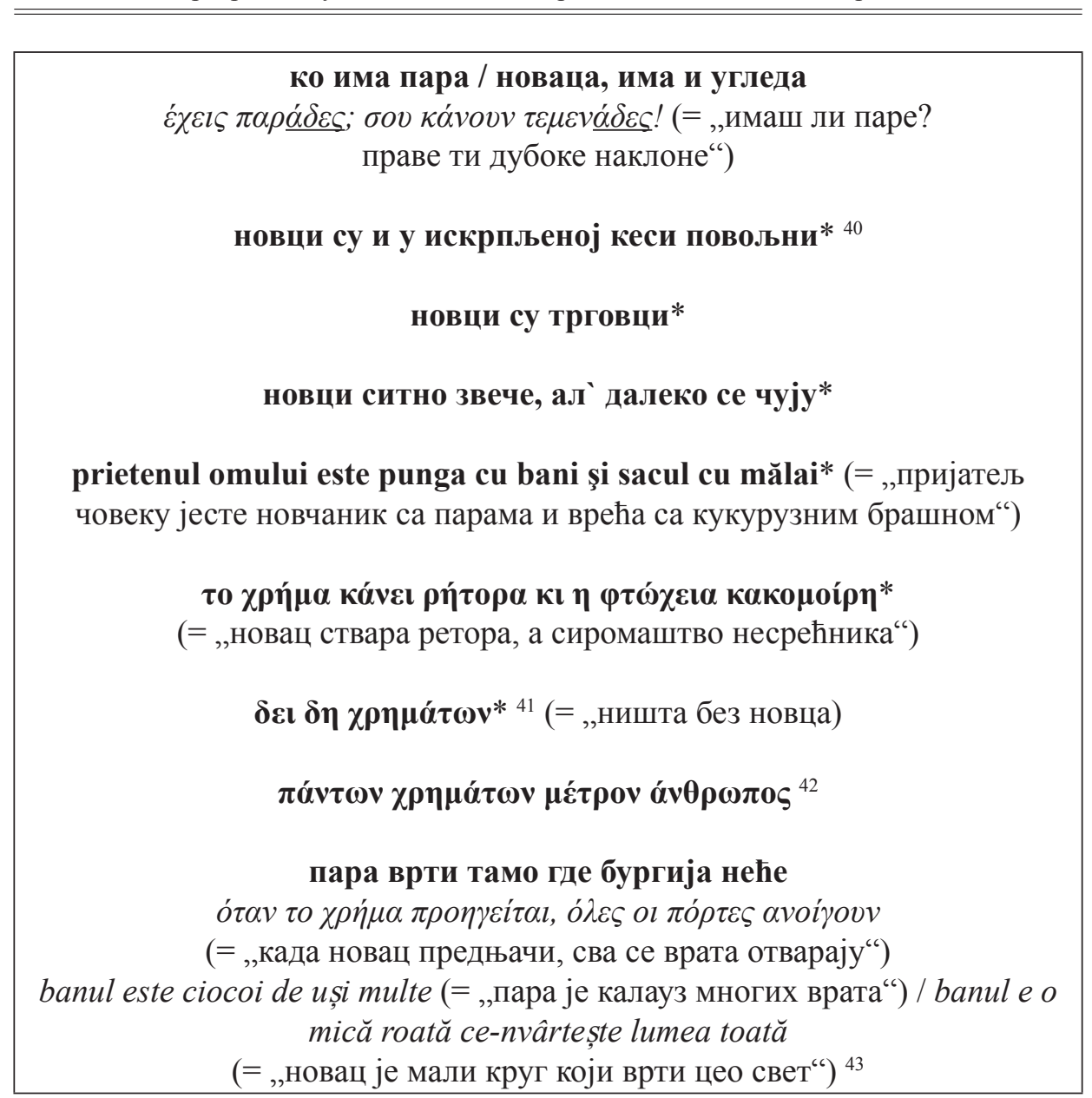

40 Паремије означене звездицом немају своје ни преводне ни приближне еквиваленте на циљним језицима.

41 Аутор овог паремиолошког израза, који се данас у савременом грчком обично наводи елиптично, јесте чувени Демостен, а у оригиналу стоји: $\delta \varepsilon \imath \delta \eta$

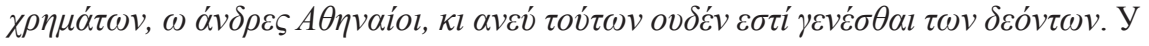
преводу на српски Јована Туромана гласи:

„Јер новаца треба, и без њих не може ништа од онога бити, што треба да буде“ (Демостен, 1912: 37).

42 Ауторство ове мудре изреке приписује се Протагори, а у преводу гласи:,новац је човек главно мерило свему“.

43 Упоредиво са познатом енглеском колокацијом: money makes the world go round. 
ФРАЗЕОЛОГИЗМИ СА КЉУЧНОМ РЕЧЈУ НОВАЦ У САВРЕМЕНОМ ...

prietenul la bani se cunoaște (= „пријатељ се по новцу познаје“)

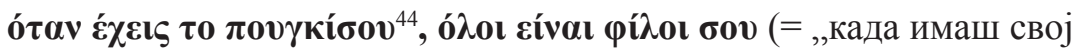
новчаник, сви су ти пријатељи“")

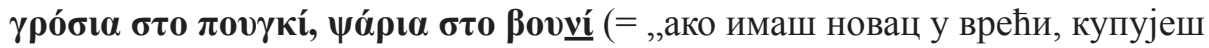
и рибу на планини“)

cu bani poate omul face, orice lucru îi place (= "новцем може човек учинити све што му се свиди“)

când vei avea în mână banul, el îți face în cap planul (= „кад имаш у руци новац, он ти у глави остварује [чини] план“)

cu bani cumperi și brânzã de iepuri (= „новцем купујеш и сир од зеца“)

Занимљиво би овде било назначити да се у грчком језику семантички смисао релативно доброг имућног стања исказује путем наредне паремије:

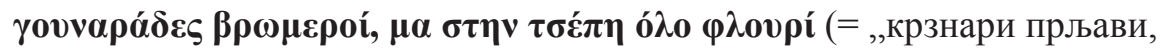
али пара [тј. златника] пуни џепови“")

за коју нисмо успели да пронађемо одговарајуће еквиваленте у румунском и српском (реч је о апсолутној нултој еквиваленцији) $)^{45}$.

Опште је познато и то да су на Балканском полуострву (па и шире) Грци добри трговци, штедљиви и да умеју располагати новцем. Како „пара на пару иде“, односно како се новац двостуко (па и вишеструко) враћа, уколико је паметно уложен у неки посао, у грчком ову мисао изражава следећа пословица такође без својих структурних и семантичких парњака у српском и румунском:

44 Реч означава врећицу у којој се накада држао новац и која се користила уместо новчаника.

45 Како се види из буквалног превода, у њој фигурира занатлија који се бави(о) изузетно прљавим и тешким послом, али који је (био и остао) прилично уносан. 


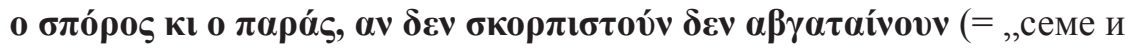
новац се не множе, ако се не потроше“)

Сви наведени грчки и румунски паремијски примери, као и један српски, припадају, сагледано са структурне тачке, категорији такозваних бинарних (или геминатних) фразеолошких конструкција за које је карактеристично како римовање лексичких елемената у виду асонанце и алитерације, тако и идентично место акцента ${ }^{46}$.

\section{7. Семантички концепти фразеологизама са компонентом новац у грчком, румунском и српском језику}

У оквиру свих анализираних фразеологизама уочавају се наредне подгрупе која указују како на позитивна семантичка поља, у смислу да поседовање новца, самим тим и ботаства, представља корист по појединца (о томе говоре претходно указане паремије) тако и на негативна, као што су наредна:

а) имати пара

\begin{tabular}{|c|}
\hline имати пара као блата / плеве / бити пун као брод \\
пливати / купати се у парама = a înota în bani / $\underline{\text { aur }}\left(=\right.$, ,злату“ $^{47}$ \\
лежати / спавати / седети на новцу / парама ${ }^{48}$ \\
\hline
\end{tabular}

б) немати (нимало) пара, при чему недостатак новца семантички указује на беду, немаштину:

46 Ради илустрације, подвучени су свега неколики примери.

47 Потпуно иста фразеолошка конструкција постоји и у мађарском: úszik a pénzben (= „пливати у парама“).

48 У мађарском, на пример, фразеологизам ül a pénzén се може посматрати као лажни пријатељ са српским сеgетии на новиу / йарама, будући да означава неког ко тиме што седи на новцу њега никоме не даје, односно указује се на веома шкртог човека. 
ФРАЗЕОЛОГИЗМИ СА КЉУЧНОМ РЕЧЈУ НОВАЦ У САВРЕМЕНОМ ...

имати пара као жаба длака = plin de bani ca broasca de păr ${ }^{49}$

бити без иједног динара / иједне паре / на ивици банкрота

*a fi / sta / se afla pe drojdie / drojdii (= „бити / налазити се на остатку / дну“)

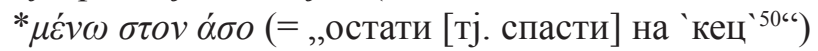

бити без пара / динара

* a nu avea nici o lăscaie

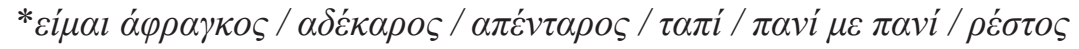

a nu avea nici o para chioară

немайи ни ирребијену йару / ни цивоњка

$\delta \varepsilon v \stackrel{\alpha}{\chi} \omega \delta \varepsilon \kappa \dot{\alpha} \rho \alpha \tau \sigma \alpha \kappa l \sigma \tau \dot{\eta}$

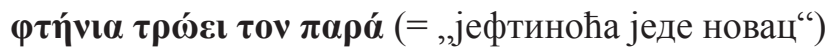

* сиройињо, и Боіуу си тешека

в) прецењивања / прецењености

a trăi pe lângă (cineva) ca banul cel bun (= ,живети поред /некога/ као добра пара“)

битии ирецењен / наяуватии / набити (коме / чему) ичену

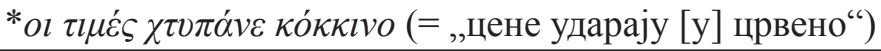

г) стећи / доћи до новца

\section{млатити / стећи / правити паре}

зарадити (лепе) паре

г) трошити (прекомерно) новац

49 Сличан фразеолошки обрт уочава се и у мађарском, уз незнатну лексичку модификацију - annyi a pénze, mint békán a toll (= „имати пара као перја жаба").

50 У овој фразеолошкој конструкцији је термин „кец“ преузет из картања. 
Предраг J. Мутавџић, Дина Дмитровић, Anastassios L. Kampouris

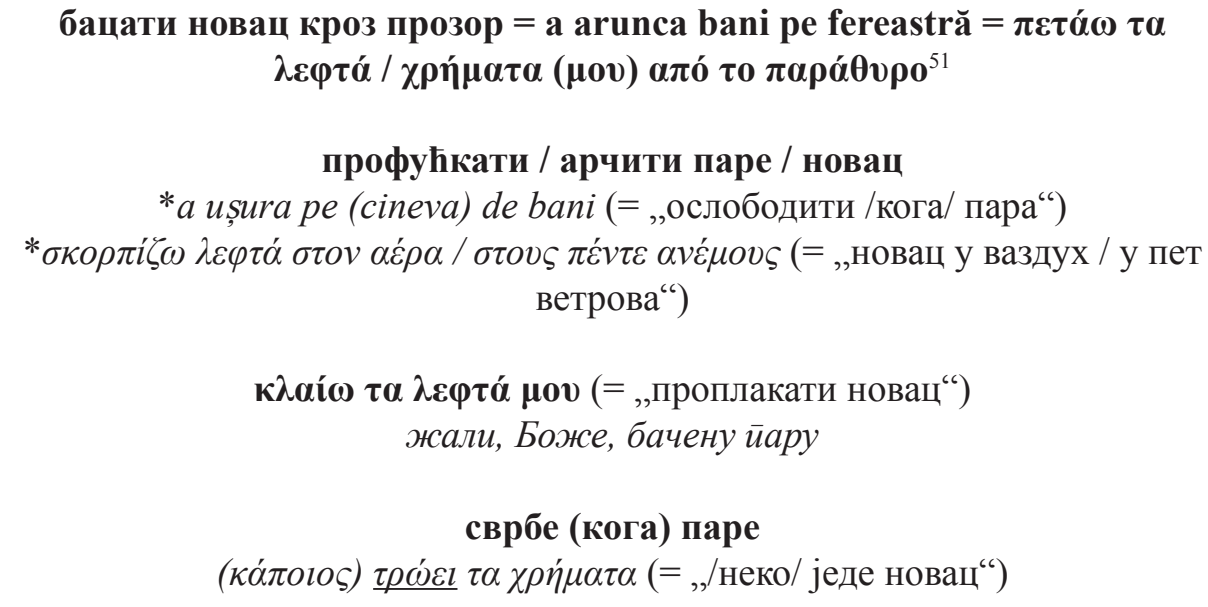

Посебан смисао великог и непотребног (нерационалног) трошења исказује се наредном грчком бинарном паремијом

51 И у мађарском постоји истоветан фразеологизам: az ablakon szórja ki a pénzt. За његову међународну раширеност треба захвалити, према мишљењу мађарског лингвисте Нађа, великом утицају Лафонтенове басне (Le Thésauriseur et le Singe) у којој мајмун баца кроз прозор новац богатог, али изузетно шкртог човека (Nagy, 1993: 36-37). 
ФРАЗЕОЛОГИЗМИ СА КЉУЧНОМ РЕЧЈУ НОВАЦ У САВРЕМЕНОМ ...

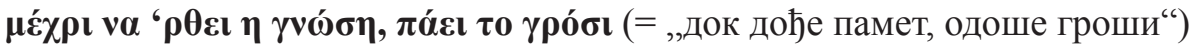

која се ни на румунски ни на српски чак ни приближно не може пренети, па је у том погледу реч о апсолутној нултој структурно-семантичкој еквиваленцији. Овај вид трошења се везује за смисао економске преваре, у смислу да се новац узалуд улаже у неки посао који, по свему судећи, неће донети корист. Супротно од ове паремије стоји наредна (такође бинарна и без одговарајућих преводних еквивалената на српском и румунском) која гласи:

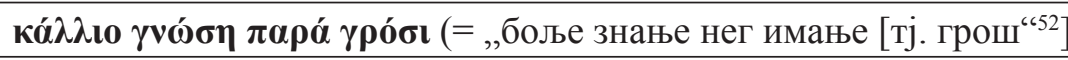

Имајући у виду њену практичну и саветодавну функцију, тежиште јој је усмерено према главном циљу у животу - према стицању знања, односно (животне) мудрости и искуства, а не према стицању новца. Ова народна филозофија се ослања на чињеници да стечено знање може остати у трајном поседу појединца, за разлику од новца чији је карактер углавном ефемеран, те да му знање и трезвеност омогућавају рационално размишљање, самим тим и рационалан однос и поступање са новцем.

д) штедети новац

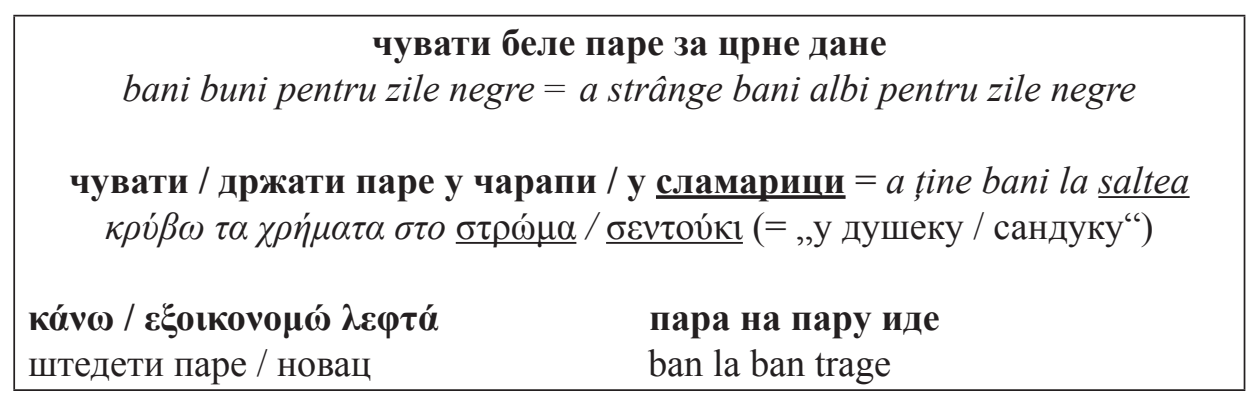

Посебан дух штедљивости, али више сагледан са стране могућег пословног ризика који подразумева да ће се новац нужно и (из) губити, исказује наредна грчка бинарна паремија без одговарајућих семантичко-структурних еквивалената у румунском и српском:

52 Овде смо у слободном преводу хтели да сачувамо што је више могуће изворни смисао и дух грчке паремије. 


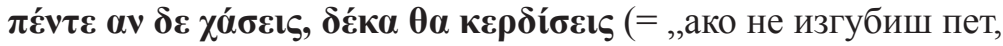
зарадићеш десет")

Ђ) безвредност

не вреди ни пет пара / ни пола гроша

nu face bani / nici (cât) o ceapă degerată

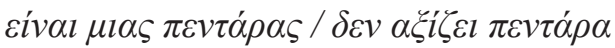

бити ситна пара / лова de doi bani / trei lulele

a nu face nici o para chioară / nici două parale = a nu face nici un ban chior / nici doi bani

е) истицање / наглашавање вредности

вреди (шта) сваку пару = merită (ceva) fiecare bănuț

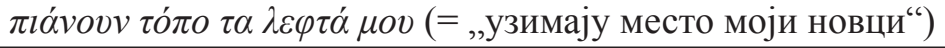

ж) велика количина новца:

масне / велике / добре / огромне паре parale bune

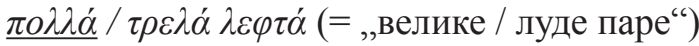

3) шкртост / тврдичлук:

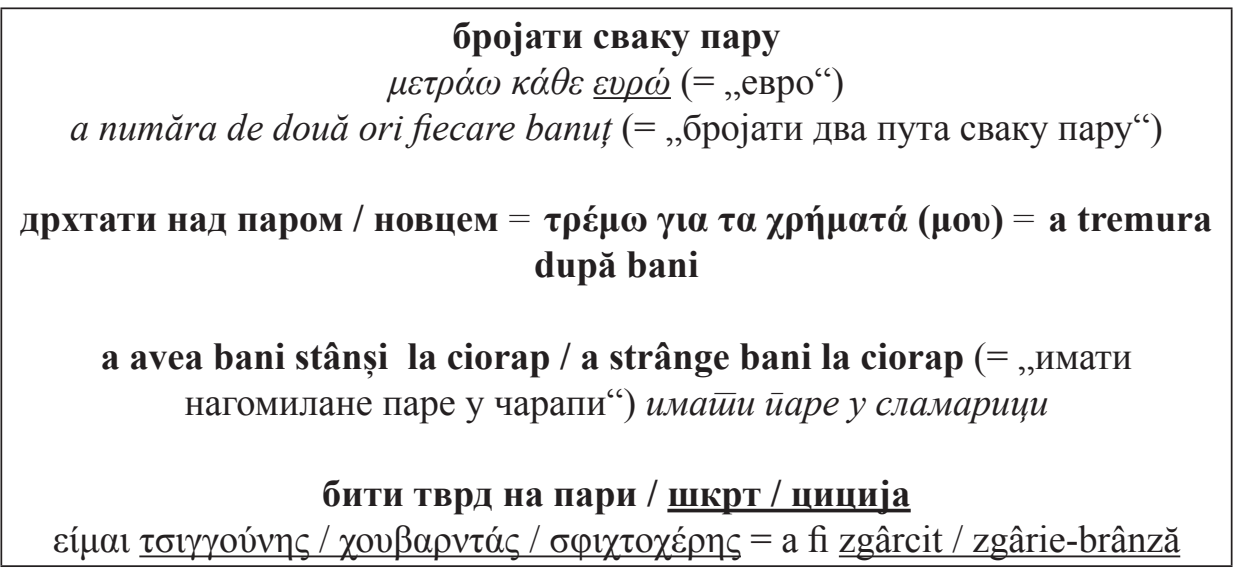


ФРАЗЕОЛОГИЗМИ СА КЉУЧНОМ РЕЧЈУ НОВАЦ У САВРЕМЕНОМ ...

и) стицање новца на рђав / непоштен начин:

a lua / împrumuta bani țigănești (= „узети / новац [на] цигански“)

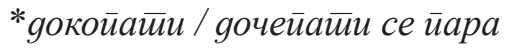

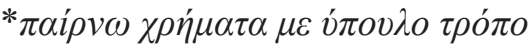

a scutura pe (cineva) de bani / buzunarele (cuiva) (= , истрести /кога/ од новца / чије новчанике")

*мазнутии / gрииитии коме йаре / новаи

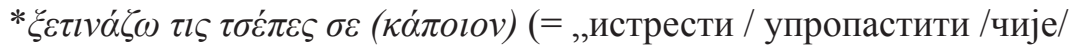
џепове“")

ј) лаковерност и/или поводљивост:

a lua (ceva) ca bani buni (= „узети /шта/ као добре паре“)

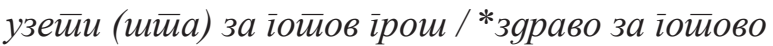

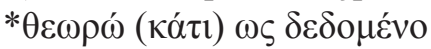

к) похлепа за новцем:

\section{бити похлепан за новцем / грамзив / лаком за новащ / пару}

a fi avid de bani / lacom de bani

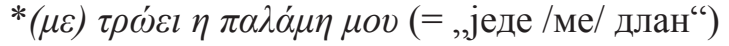

извући и последњу пару од (кога)

a stoarce de bani pe (cineva) (= „исцедити паре од /кога/“")

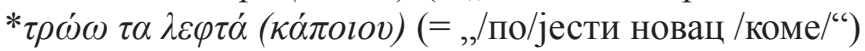

Назначимо још и то да у одређеним метафоричким концептима фразеологизми са лексичком компонентом новач могу носити и наредно значење:

л) нечије личне незаитересованости:

a lăsa pe (cineva) în banii / boii lui (= „оставити /кога/ у његовим парама / воловима")

*їлеgайи своја йосла / остиайи ӣо сиирани

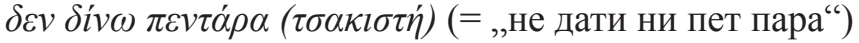


Предраг J. Мутавџић, Дина Дмитровић, Anastassios L. Kampouris

љ) нечије (углавном негативне) карактеризације:

a ști câte parale face (cineva) (= ,знати колике паре чине /некога/“") знати (кога) као злу пару / *свој џеп

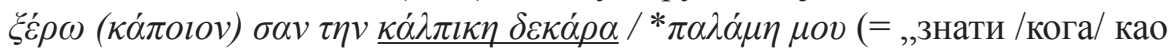
превртљиву десетодинарку / *свој длан“)

м) испољавање нечијег незадовољства, љутње:

a lua pe (cineva) la trei parale (= „узети /кога/ на три паре“)

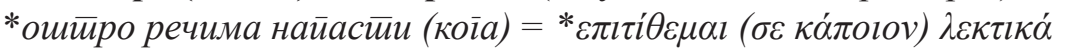

н) изазивања нечије негативне реакције:

a face pe (cineva) de trei parale (=, „/у/чинити /кога/ од три паре“)

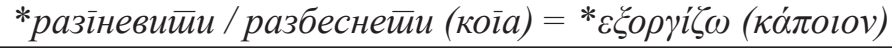

Исто тако, из примера се запажа да највећи проценат свих забележених фразеолошких конструкција припада категорији стицања и трошења новца у којима новац носи своје основно значење.

\section{8. Закључак}

Toți se plâng de bani, de minte nimeni. ${ }^{53}$ (румунска народна пословица)

На основу анализираних примера, могуће је да се увиди следеће:

1. И поред тога што у формирању свих забележених фразеологизама учествује један број лексема различитог етимолошког порекла, које се односе на појам новца, апсолутну превагу ипак

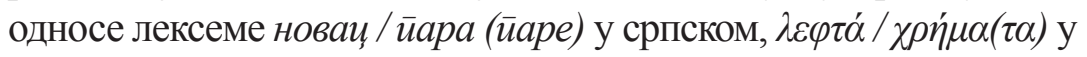
грчком те $\operatorname{ban}(i)$ у румунском. У сва три језика се као парасинонимна јавља и турцизам тара́s / para. У овом погледу се уочава међулексичка подударност. Исто тако, код свих фразеологизама

53 „Сви плачу за парама, за памећу нико“ (превод је наш). 
ФРАЗЕОЛОГИЗМИ СА КљУЧНОМ РЕЧЈУ НОВАЦ У САВРЕМЕНОМ ...

код којих је уочена комутација указаних лексема не долази ни до промене смисла нити значења фразеолошких конструкција.

2. Све и даље сачуване у језику лексеме страног порекла (а које су биле средство плаћања у ранијим историјским периодима) носе искључиво конотацију мале новчане вредности, односно „ситнине“.

3. Комутација лексема код свих фразеологизама образованих од кључне нумизматичке лексеме која је ушла у сваки од разматраних језика у ранијим историјским периодима није могућа, с обзиром да је реч о сада већ петрифицираним конструкцијама.

4. Између фразеолошких слика разматраних савремених балканских језика преовлађује релативно јасно дефинисана идиотипичност у погледу састава (односно, унутрашње грађе) и семантике када је реч о фразеологизмима са кључном речју новац. У односу на укупан број свих забележених фразеологизама, они учествују са 71,42\%, односно реч је о 175 примера.

5. Између три фразеолошке слике уочено је:

a) потпуно структурно-семантичко поклапање у 67 примера, што чини 27,34\% од укупног броја забележених фразеолошких јединица, и то између грчког и румунског (17), румунског и српског (32) те грчког и српског (18);

б) делимично структурно-семантичко поклапање у 51 пример, односно у свега 20,81\%;

в) нулто структурно-семантичко поклапање у 127 примера, односно 51,83\%.

6. Код свих забележених паремија, без обзира на полазни језик, уочен је углавном апсолутни нулти степен структурно-семантичке еквиваленције.

7. Највећи степен подударности како у структури тако и у семантици исказује се код четири наредна концепта:
a) концепта немања новца,
б) концепта трошење новца,
в) концепта штедње новца,
г) концепта тврдичлука.

8. Све уочене разлике, а посебно оне уколико имамо на уму нулти степен структурно-семантичке подударности, недвосмислено указују на то да је сваки народ на свој особит друштвено-културолошки и практичан начин приписао новцу ону улогу и значај који је за њега био од посебне важности. 
Предраг J. Мутавџић, Дина Дмитровић, Anastassios L. Kampouris

9. Све ово указује на то да у сва три језика преовлађују како друкчији начини концептуализације фразеологизама тако и сасвим друкчији начини фразеологизације. У овом погледу се може рећи да су разматрани балкански језици сасвим хомотипични.

10. Разматране фразеолошке конструкције у сва три језика тичу се не само човековог емотивног стања, односно понашања, у вези са новцем него и описују друштвене класно-економске односе. У културолошком погледу, чињеница је да су одувек или поседовање новца или беспарица знатно утицали и на успостављање и на одржавање веза између људи. А како су показале и паремије које се тичу моћи коју новац пружа, сва три народа су изградила јасан морално-социјални став - да није рђаво бити имућан, с обзиром да је новац ,универзални језик“ који се у сваком друштву одлично разуме.

11. Закључци нашег контрастивног и компаративног сагледавања фразеолошких јединица одабраних на основу кључне речи новач могу имати значај и примену код превођења са неког или на неки од разматраних балканских језика. Познато је да културолошки аспект игра важну улогу у процесу превођења те да на себи својствен начин „боји“ појединачне лексеме. Кроз препознавање тих боја зближавамо се како са језиком, тако и са менталитетом и културом једног народа.

\section{ЛИТЕРАТУРА}

\section{1. Извори}

a) једнојезични речници:

Croitoru-Bobârniche, N. (1996). Dicționar de argou al limbii române. Slobozia: Editura Arnina.

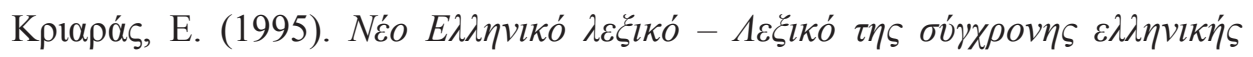

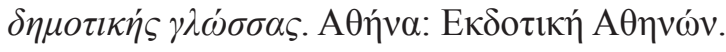

Matešić, J. (1982). Frazeološki rječnik hrvatskoga ili srpskoga jezika. Zagreb: Školska knjiga. 
ФРАЗЕОЛОГИЗМИ СА КЉУЧНОМ РЕЧЈУ НОВАЦ У САВРЕМЕНОМ ...

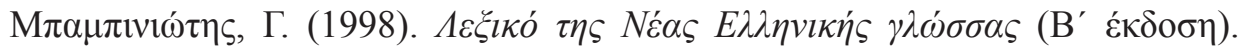

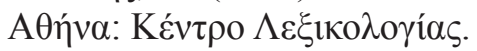

Оташевић, Ђ. (2012). Фразеолошки речник срӣской језика. Нови Сад: Прометеј. Речник срйскохрвайскоі̄ књижевної језика (1-6). (1995). Нови Сад: Матица Српска.

Речник срйскохрвайскої књижевної и нарояної језика САНУ (том 1-19). Београд: Институт за српски језик САНУ.

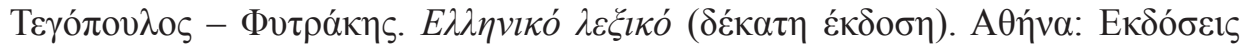
Aprovía, 1995.

http://www.greek-language.gr/greekLang/modern_greek/tools/lexica/triantafyllides/ https://dexonline.ro/

http://www.gnomikologikon.gr/greek-proverbs.php?page=15

б) двојезични речници на балканским језицима:

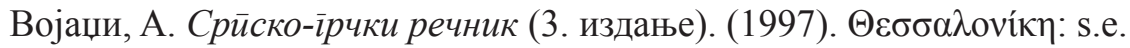

Мутавџић, П. Грчко-срйски речник ияиома. (1. издање). (2007). Београд: ИК Јасен.

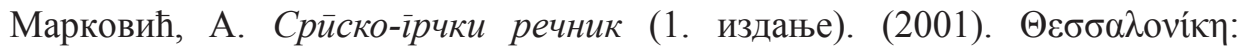

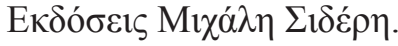

Стојановић, М. - Балаћ, А. (2009). Грчко-сритски речник (2. издање). Београд: Завод за уџбенике.

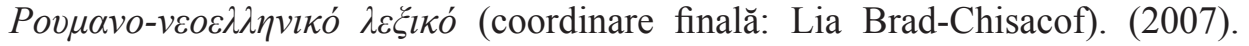
București: Editura Demiurg.

Tomici, M. (1986). Dicționar român-macedonean / Романско-макеgонски речник. București-Скопје: Editură Științifică și encilopedică-Македонска книга.

Tomici, M. (1986). Dicționar macedonean-român / Макеgонско-романски речник. București-Скопје: Editură Științifică și encilopedică-Македонска книга.

в) двојезични речници на другим страним језицима:

Bantaș, A. (1998). Dicționar englez-român/român-englez. București: Teora.

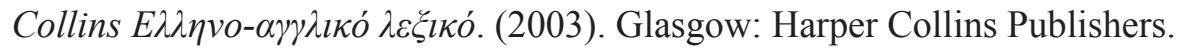

Collins Greek-English Dictionary. (1997). Glasgow: Harper Collins Publishers.

Dizionario Greco moderno-Italiano, Italiano-Greco moderno. (2006). Bologna: Zanichelli editore.

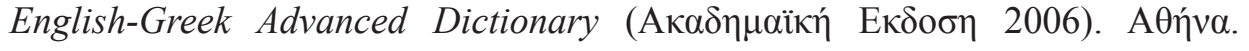

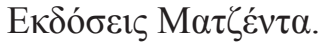




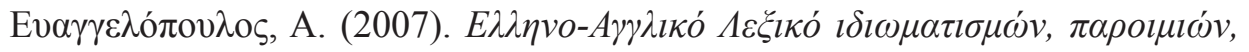

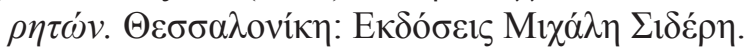

Marin, S. (2005). English-Greek Lexicon of Idioms and Slang. Athens: Aheadbooks.

Marin, S. (2010). Greek-English Lexicon of Idioms and Slang (2nd edition). Athens: Aheadbooks.

Stavropoulos, D. N. (2012). Oxford Greek-English Learner`s Dictionary. Oxford: Oxford University Press.

Stavropoulos. D. N. - Horby, A. S. (2011). Oxford English-Greek Learner `s Dictionary. Oxford: Oxford University Press.

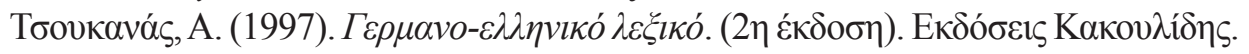

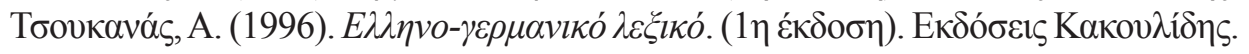

г) тројезични речник:

Fotea, M. - Țăranu, E. (2004). Dicționar frazeologic român selectiv, cu echivalente în limbile franceză, engleză, neogreacă. Iași: Lumen.

\section{2. БИБЛИОГРАФИЈА}

Aglietta, M. - Orléan, A. (2004). Novac i suverenost. Zagreb: Tehnička knjigaGolden marketing.

Camerer, C. - Loewenstein, G. - Prelec, D. (2005). Neuroeconomics: How Neuroeconomics Can Inform Economics. Journal of Economic Literature. Vol. XLIII (March, 2005), 9-64.

Ciorănescu, A. (2002). Dicționarul etimologic al limbii române. București: Editura Saeculum I.O.

Davidson, J. (1998). Courtesans and Fishcakes: The Consuming Passions of Classical Athens. London: Fontana Press.

Демостиенове бесеgе (превео, објаснио и предговор написао др Јован Туроман). (1912). Београд: СКЗ.

Graziani, A. (2003). The Monetary Theory of Production. Cambridge: Cambridge University Press.

Hrvatska enciklopedija. (2005). svezak 7, Mal-Nj. (glavni urednik: August Kovačec). Zagreb: Leksikografski zavod „Miroslav Krleža”.

Lang, E. (1983). „Lexikon als Modellkomponente und Wörterbuch als lexikographisches Produkt: ein Vergleich als Orientierungshilfe“. Y: Joachim Schildt - Dieter Viehweger, Hrsg. Lexikographie von heute und das Wörterbuch von morgen. Analysen - Probleme - Vorschläge (Linguistische Studien Reihe A, Arbeitsbericht 109). (pp. 76-91). Berlin [DDR]: Akademie-Verlag. 
ФРАЗЕОЛОГИЗМИ СА КЉУЧНОМ РЕЧЈУ НОВАЦ У САВРЕМЕНОМ ...

Мала енииклойеgија Просвет̄а - ойшйа енцииклойеgија. (1978). (треће издање). Књига 2: Југославија, К-П. Београд: Просвета.

Mankiw, N. G. (2006). Osnove ekonomije. Zagreb: Mate.

Маслова, В. А. (2007). Линівокульйуролоіия (3-е издание). Москва: Издательский центр „Академия“.

McHugh, J. F. (2009). A Critical and Exegetical Commentary on John 1-4. London - New York: T\&T Clark International.

Mishkin, F. S. (2007). The Economics of Money, Banking and Financial Market (Alternate Edition). Boston: Addison Wesley.

Мршевић-Радовић, Д. (1987). Фразеолошке ілаїолско-именичке синйайме y савременом срисккохвайском језику. Монографије. Књига LX. Београд: Филолошки факултет.

Nagy, O. (1993). Mi fán terem? Budapest: Gondolat-Tálentum.

Păun, C. (2010). Banii, băncile centrale, politica monetară și reglementarea sistemului bancar modern. Revista Oeconomia. No. 2 (2010), 1-22.

Пермяков, Г. Л. (1988). Основы сиирукииурной йаремиолойий. Серия „Исследования по фольклору и мифологии Востока“. Москва: Издательство „Наука“.

Smithin, J. N. (2000). What is Money? London: Routledge.

Spinella, M. - Yang, B. - Lester, D. (2007). Development of the Executive Personal Finance Scale. International Journal of Neuroeconomics. No. 117, 301-313.

Spinella, M. - Yang, B. - Lester, D. (2008). Prefrontal Cortex Dysfunction and Attitudes Toward Money: A Study in Neuroeconomics. The Journal of Socio-Economics. No. 37 (2008), 1785-1788.

Tobin, J. (2008). The New Palgrave Dictionary of Economics (edited by: Steven N. Durlauf and Lawrence E. Blume). (доступно на следећој страници интернета: http://www.dictionaryofeconomics.com/article?id=pde2008_ M000217> doi:10.1057/9780230226203.1126).

Weber, B. - Rangel, A. - Wibral, M. - Falk, A. (2009). The Medial Prefrontal Cortex Exibits Money Illusion. PNAS. Vol. 106, No. 13 (March 31, 2009). $5025-5028$.

Шипка, М. (2011). Структура и значење ироничних фразема у српском језику. Наш језик XLII, св. 3-4 (2011), 25-28. 
Предраг J. Мутавџић, Дина Дмитровић, Anastassios L. Kampouris

Predrag Mutavdžić

Dina Dmitrović

Anastassios Kampouris

\title{
IDIOMATIC EXPRESSIONS CONTAINING THE LEXEME MONEY IN CONTEMPORARY GREEK, ROMANIAN AND SERBIAN
}

\begin{abstract}
Summary
In the history of human society, money has always played an active role which could be described as a role of a mediator with so-called "hypnotic" power and strong symbolical meanings. As it gradually became one of dominant factors in human life, it gradually entered as a key word in many idiomatic expressions in almost every language in the world. Therefore, the main focus of this paper is on idiomatic expressions and paremias in three contemporary Balkan languages Greek, Romanian and Serbian which are constructed either by using the primary lexeme money or by using any secondary lexemes (such as grosh, thaler, kreutzer etc.) which used to be formal currencies in former historical periods. These idioms, which do not form a large thematic group, have been analysed both comparatively and contrastively. As there is a large variety of denominations of money in idioms in each of the aforementioned languages, there are some instances where free commutation of lexemes is either possible (the meaning remains unchangeable) or impossible because they have already become petrified constructions.

Based on the conducted analysis, the results show that in terms of structure zero phraseological equivalence is predominant (127 examples, 51,83\%), while in terms of semantics absolute concordances amongst the selected idioms have been noted only in the following four concepts: "'lack of money", "money spending", "money saving", "stringiness". This is not so peculiar, if we bear in mind the fact that people have had more or less universal relation(s) to money, that money in each and every society has had a slightly different role and that particular significances have been associated with it in time due to special sociocultural differences. Having in view how the "picture of money" is represented in the three examined Balkan languages, it can be concluded that it is homotypical, as different ways both of construction and conceptualization of idiomatic expressions prevail in each language.
\end{abstract}

Key words: money, contemporary Greek, Romanian, Serbian, idiomatic expressions, equivalency 